\title{
Prefrontal-Bed Nucleus Circuit Modulation of a Passive Coping Response Set
}

\author{
(DShane B. Johnson, ${ }^{1}{ }^{-E}$ Eric B. Emmons, ${ }^{1}$-Ryan T. Lingg, ${ }^{2}$ - Rachel M. Anderson, ${ }^{2}$ Sara A. Romig-Martin, ${ }^{2}$ \\ (D)Ryan T. LaLumiere, ${ }^{1,2,4}$ (D) Nandakumar S. Narayanan, ${ }^{1,3,4}$ Victor Viau, ${ }^{5}$ and (Dason J. Radley ${ }^{1,2,4}$ \\ ${ }^{1}$ Interdisciplinary Neuroscience Program, ${ }^{2}$ Department of Psychological and Brain Sciences, ${ }^{3}$ Department of Neurology, Carver College of Medicine, \\ ${ }^{4}$ Iowa Neuroscience Institute, University of Iowa, Iowa City, Iowa 52242, and ${ }^{5}$ Department of Cellular and Physiological Sciences, University of British \\ Columbia, Vancouver, British Columbia V6T 1Z3, Canada
}

One of the challenges facing neuroscience entails localization of circuits and mechanisms accounting for how multiple features of stress responses are organized to promote survival during adverse experiences. The rodent medial prefrontal cortex (mPFC) is generally regarded as a key site for cognitive and affective information processing, and the anteroventral bed nuclei of the stria terminalis (avBST) integrates homeostatic information from a variety of sources, including the mPFC. Thus, we proposed that the mPFC is capable of generating multiple features (endocrine, behavioral) of adaptive responses via its influence over the avBST. To address this possibility, we first optogenetically inhibited input to avBST from the rostral prelimbic cortical region of mPFC and observed concurrent increases in immobility and hypothalamo-pituitary-adrenal (HPA) output in male rats during tail suspension, whereas photostimulation of this pathway decreased immobility during the same challenge. Anatomical tracing experiments confirmed projections from the rostral prelimbic subfield to separate populations of avBST neurons, and from these to HPA effector neurons in the paraventricular hypothalamic nucleus, and to aspects of the midbrain periaqueductal gray that coordinate passive defensive behaviors. Finally, stimulation and inhibition of the prelimbic-avBST pathway, respectively, decreased and increased passive coping in the shock-probe defensive burying test, without having any direct effect on active coping (burying) behavior. These results define a new neural substrate in the coordination of a response set that involves the gating of passive, rather than active, coping behaviors while restraining neuroendocrine activation to optimize adaptation during threat exposure.

Key words: bed nucleus; HPA; passive coping; prelimbic; shock probe defensive burying; ventrolateral periaqueductal gray area

Significance Statement

The circuits and mechanisms accounting for how multiple features of responses are organized to promote adaptation have yet to be elucidated. Our report identifies a prefrontal-bed nucleus pathway that organizes a response set capable of gating passive coping behaviors while concurrently restraining neuroendocrine activation during exposure to inescapable stressors. These data provide insight into the central organization of how multiple features of responses are integrated to promote adaptation during adverse experiences, and how disruption in one neural pathway may underlie a broad array of maladaptive responses in stressrelated psychiatric disorders.

\section{Introduction}

Stress responses involve the induction of neuroendocrine hypothalamo-pituitary-adrenal (HPA) and sympathetic systems for

Received June 4, 2018; revised Nov. 16, 2018; accepted Dec. 12, 2018.

Author contributions: S.B.J. and J.J.R. wrote the first draft of the paper; S.B.J., E.B.E., N.S.N., V.V., and J.J.R. edited the paper; S.B.J., E.B.E., R.T. LaLumiere, N.S.N., V.V., and J.J.R. designed research; S.B.J., E.B.E., R.T. Lingg, R.M.A., S.A.R.-M., and J.J.R. performed research; S.B.J., E.B.E., S.A.R.-M., R.T. LaLumiere, N.S.N., V.V., and J.J.R. analyzed data; S.B.J. and J.J.R. wrote the paper.

This work was supported by National Institutes of Health R01 MH-095972, R56 MH-095972, and NARSAD Independent Investigator Grants.

The authors declare no competing financial interests.

Correspondence should be addressed to Jason J. Radley at jason-radley@uiowa.edu. the mobilization and redistribution of bodily resources to any challenge that overwhelms, or is perceived to overwhelm, selective homeostatic systems of the individual (Selye, 1980; Day, 2005). The extent to which one or both of these systems are recruited may vary, depending on the particular challenge at hand, and the extent to which these responses complement situation-specific behavioral adaptations. Although CNS substrates have been proposed to serve as sites for the coordination of multiple response features (e.g., behavioral and endocrine) into 
patterns or sets (Mason et al., 1976), much of the past work has examined circuits and mechanisms accounting for one feature in isolation from the other.

The rodent medial prefrontal cortex (mPFC) is generally regarded as a key site for cognitive and affective information processing, although its capacity to also modulate homeostatic functions makes it an ideal candidate organizer of such features into response sets during stressor exposure. Multiple lines of investigation have implicated $\mathrm{MPFC}$ in the modulation of a variety of responses to environmental stimuli, such as cardiovascular activity (Neafsey, 1990; Fisk and Wyss, 1997; Tavares et al., 2009), HPA output (Diorio et al., 1993; Akana et al., 2001; Figueiredo et al., 2003; Spencer et al., 2005), defensive behaviors (Bandler et al., 2000; Keay and Bandler, 2001; Franklin et al., 2017), and fear conditioning (Morgan and LeDoux, 1995; Sotres-Bayon and Quirk, 2010; Gilmartin et al., 2014). Although circuit analyses governing $\mathrm{mPFC}$ modulation of each response feature have tended to focus on prefrontal input to amygdaloid, hypothalamic, and anatomically related midbrain areas, only a few studies to date have critically examined the involvement of efferent projections to the bed nuclei of the stria terminalis (BST; Radley et al., 2006, 2009; Glangetas et al., 2017). Given the fundamentally important role of BST as a neural hub for the organization of adaptive responses to downstream effector regions under a wide array of adverse experiences (Walker et al., 2003; Davis et al., 2010; Crestani et al., 2013; Fox et al., 2015; Daniel and Rainnie, 2016; Lebow and Chen, 2016), progress in the field will require a clearer understanding of prefrontal-BST interactions and how these pathways assemble coherent patterns of responses.

We have previously identified anteroventral BST (avBST) as a source of GABAergic neurons that issue divergent projections to HPA-effector neurons in the paraventricular nucleus of the hypothalamus $(\mathrm{PVH})$ and to the ventrolateral periaqueductal gray area (PAG), respectively, capable of restraining increases in HPA output and immobility behavior in response to inescapable challenges. The present study addressed the hypothesis that the $\mathrm{mPFC}$ is capable of coordinating multiple features (endocrine, behavioral) into response patterns during inescapable challenges via its influence over avBST (Sesack et al., 1989; Hurley et al., 1991; Radley et al., 2009). An initial experiment showed that optogenetic inhibition of axonal input from the rostral prelimbic cortex to the avBST led to concurrent increases in immobility and HPA output during tail suspension in male rats, whereas photostimulation of this pathway decreased immobility during the same challenge. Anatomical tracing experiments confirmed projections from the rostral prelimbic subfield to separate populations of avBST neurons, and from these to the paraventricular hypothalamus (HPA) and ventrolateral PAG (immobility). Finally, photostimulation and inhibition of the prelimbic $\rightarrow$ avBST pathway, respectively, increased and decreased passive coping (immobility) in the shock-probe defensive burying test, without having any direct effect on active coping (burying) behavior. These results define a common neural substrate in a response set for gating passive, instead of driving active, coping behaviors while also restraining neuroendocrine activation to optimize adaptation during threat exposure.

\section{Materials and Methods}

\section{Animals and treatments}

Adult male Sprague-Dawley rats, 225-250 g at time of arrival (Charles River Laboratories), were acclimated for at least $7 \mathrm{~d}$ before surgery in an AALAC-approved vivarium with ad libitum access to food and water. All procedures were approved by the University of Iowa Institutional Ani- mal Care and Use Committee and in accordance with National Institutes of Health Guide for the Care and Use of Laboratory Animals.

\section{Surgeries}

Optogenetic experiments. Rats were anesthetized with $4 \%$ isoflurane in oxygen, then placed in a stereotaxic frame (Kopf Instruments) before receiving preemptive analgesia $(2 \mathrm{mg} / \mathrm{kg}$ meloxicam $)$. Surgical anesthesia was maintained with $1.5-2 \%$ isoflurane. An incision was made to expose the skull for a craniotomy above the region of interest. Bilateral injections of adeno-associated virus (AAV; serotype 5, $0.30 \mu \mathrm{l} /$ side) were directed at either prelimbic [PL; anteroposterior (AP): $3.75 \mathrm{~mm}$; mediolateral (ML): $0.65 \mathrm{~mm}$; dorsoventral: $3.5 \mathrm{~mm}$ (Gourley et al., 2009); all relative to bregma] or avBST (AP: $-0.10 \mathrm{~mm}$; ML: $1.20 \mathrm{~mm}$; DV: $7.45 \mathrm{~mm}$ ). Rats received injections of either AAV5-CaMKII-ChR2(E123A)-eYFP (PL: ChR2 groups), AAV5-CaMKII-eNpHR3.0-eYFP (PL:Halo groups), AAV5-hSyn-eNpHR3.0-eYFP (avBST:Halo group), and AAV5-eYFP under either the CaMKII (PL:YFP control groups) or hSyn promoter (avBST:YFP group). After AAV injection, fiber optics (200 $\mu \mathrm{m}$ diameter, $0.37 \mathrm{NA}$; Thorlabs) secured inside steel ferrules (Plastics One) were placed immediately dorsal to either avBST (AP: -0.10 ; ML: 2.50; DV: $\left.-6.70 ; 8^{\circ}\right)$ or ventrolateral PAG (AP: $-7.45 ; \mathrm{ML}: 1.80 ; \mathrm{DV}: 5.20 ; 10^{\circ}$ ) and then secured with dental cement and surgical screws. After 5 weeks recovery, rats were handled daily by the experimenter and habituated to the testing room for 1 week before carrying out the behavioral procedures.

Tracer injections. Biotinylated dextran amine (BDA) deposits were placed in PL ( $120 \mu \mathrm{l}$; AP: $3.75 \mathrm{~mm}$; ML: $0.65 \mathrm{~mm}$; DV: $3.5 \mathrm{~mm}$ ) for anterograde labeling of PL terminals in avBST. Fluoro-Gold (FG) deposits were placed in avBST $(120 \mu \mathrm{l}$; AP: $-0.10 \mathrm{~mm}$; ML: $1.20 \mathrm{~mm}$; DV: $-7.45 \mathrm{~mm}$ ) for retrograde labeling of avBST-projecting PL neurons. Finally, cholera toxin $\mathrm{b}(\mathrm{CTb})$ deposits were placed in ventrolateral PAG (AP: -7.45; ML: 1.80; DV: 5.20; $10^{\circ}$ ) for retrograde labeling of ventrolateral PAG-projection avBST neurons (see Figs. 3, 4). After a 2 week recovery period, rats bearing tracer deposits were subjected to the shock probe defensive burying test (as described in Stressors and behavioral observations) and perfused 90 min after shock for subsequent immunolocalization of Fos.

\section{Hormone assays}

Two days before tail suspension, rats were implanted with indwelling jugular catheters as previously reported (Ericsson et al., 1994; Radley et al., 2006). Jugular catheters (polyethylene PE-50) containing sterile heparin-saline $(50 \mathrm{U} / \mathrm{ml})$ were implanted under isoflurane anesthesia as described above. The sealed catheter was positioned with its internal SILASTIC (Dow Corning) tip positioned at the atrium and the remaining length was exteriorized at the nape in the interscapular region. On the experiment day, at the beginning of the circadian corticosterone (CORT) trough at $06: 00 \mathrm{~h}$, rats were brought to the procedure room where jugular catheters were connected to sterile $1 \mathrm{ml}$ syringes and flushed with sterile heparin-saline. Dust caps were removed from each implanted ferrule and the exposed fiber optics were cleaned with lens paper before being connected to fiber optic connector leashes $(200 \mu \mathrm{m}$ diameter, $0.37 \mathrm{NA}$; Thorlabs). Following $\geq 90 \mathrm{~min}$ habituation, blood samples $(\sim 200 \mu \mathrm{l})$ were taken before stress $(0 \mathrm{~min})$ for estimation of basal adrenocorticotropic hormone $(\mathrm{ACTH})$ and CORT levels. Subsequent samples were taken immediately following tail suspension $(10 \mathrm{~min})$ as well as 30,60 , and 90 min after the onset of tail suspension. Each sample was immediately placed in a chilled $1.5 \mathrm{ml}$ microcentrifuge tube containing a preservative (15 $\mu \mathrm{l}$ EDTA/ aprotinin), then centrifuged for $20 \mathrm{~min}$ before fractionation and storage at $-80^{\circ} \mathrm{C}$. Plasma ACTH levels were measured with a two-site radio-immunometric assay (MP Biomedicals) and Iodine- 125 as a tracer. Intra- and inter-assay coefficients of variation were 3 and 7\%, respectively, and sensitivity was $1.5 \mathrm{pg} / \mathrm{ml}$. Plasma CORT was measured without extraction with rabbit antisera raised against corticosterone-BSA with ${ }^{125} \mathrm{I}$-corticosterone-BSA as a tracer (MP Biomedicals). Intra- and inter-assay coefficients of variation were respectively 5 and $10 \%$, with a sensitivity of $8 \mathrm{ng} / \mathrm{ml}$.

\section{Stressors and behavioral observations}

Tail suspension. Tail suspension was used as an expedient assay to assess concurrent changes in stress-evoked behavioral and HPA output while 
performing optogenetic manipulations. This behavioral assay was developed in mice (Steru et al., 1985), has been adapted for use in rats (Chermat et al., 1986; Izumi et al., 1997; Zhang et al., 2008; Yang et al., 2014; Paumier et al., 2015), and elicits robust stress responses (Strekalova et al., 2004; Stone and Lin, 2008). Rats are suspended by the tail for $10 \mathrm{~min}$ so that the hindlimbs were elevated and forelimbs were allowed to touch the floor of the cage (Chermat et al., 1986). Immobility was scored as total time spent in a behavioral state devoid of head and limb movement. Episodes of immobility were counted toward the total if they occurred after the first minute of tail suspension and lasted for $5 \mathrm{~s}$ or longer.

Shock probe defensive burying test. This assay was developed by Treit et al. (1981) and allows for the differential assessment of both active and passive coping behaviors (De Boer and Koolhaas, 2003). Rats were first individually handled and habituated over $6 \mathrm{~d}$ to $30 \times 30 \mathrm{~cm}$ cages containing food pellets and $6 \mathrm{~cm}$ of standard bedding. On Day 7, a shock probe connected to a current source was secured inside the cage such that it protruded $6 \mathrm{~cm}$ into the cage and $1 \mathrm{~cm}$ above the bedding. Rats were connected to fiber-optic leashes and placed inside the cage facing away from the probe. Upon investigating and contacting the novel probe, rats received a single $2 \mathrm{~mA}$ shock. Photoillumination proceeded for $10 \mathrm{~min}$ as described in the Photoillumination section. Behavior was video recorded (GoPro) from the moment rats were placed inside the cage until the moment they were removed $10 \mathrm{~min}$ after the shock. Behavior was later scored by a blinded observer for approach latency, immobility, burying, ambulation, rearing, and grooming behavior. Heat maps were produced from representative examples of animals from each group for $10 \mathrm{~min}$ following shock. Two-dimensional probability densities were then computed in R.

\section{Photoillumination}

Laser power was adjusted to deliver $10 \mathrm{~mW}$ power at the tip of the implanted fiber optics, which is sufficient to activate opsins with a 0.46 radius sphere below the termination of the fiber optic (Yizhar et al., 2011; Huff et al., 2013). Rats bearing ChR2 microinjections and their YFP control counterparts received $473 \mathrm{~nm}$ light (OptoEngine) pulses at $20 \mathrm{~Hz}$ (5 ms width; Master-9 pulse generator). Halorhodospin (Halo) and control animals received constant $561 \mathrm{~nm}$ light (Laser Century). Photoillumination proceeded for the duration of the stressor $(10 \mathrm{~min})$.

\section{Optrode recordings}

In a separate group of animals, rats were injected in the prelimbic region of cortex (AP: +3.75 , ML: +0.65 , DV: $-3.5 \mathrm{~mm}$ relative to bregma) with either AAV5-CaMKII-ChR2(E123A)-eYFP or AAV5-CaMKII-eNpHR3.0eYFP. At least 4 weeks later, these animals underwent stereotaxic surgery. Animals were anesthetized with $4 \%$ isoflurane. A surgical level of anesthesia was induced with intraperitoneal injections of ketamine $(100 \mathrm{mg} /$ $\mathrm{kg})$ and xylazine $(10 \mathrm{mg} / \mathrm{kg})$. Supplementary injections of ketamine (30 $\mathrm{mg} / \mathrm{kg}$ ) were given as needed. The scalp was retracted and the skull leveled between bregma and lambda. A craniotomy was made above the avBST of the left hemisphere (AP: -0.10 , ML: +1.20 ). Finally, holes were drilled for two skull screws and the ground wire.

Recordings were made with a combined microwire array and optical fiber, or "optrode" (MicroProbes for Life Science). The optrode was slowly lowered $(0.1 \mathrm{~mm} / \mathrm{min})$ into the dorsal-most aspect of the avBST (DV: $-7.2 \mathrm{~mm}$, relative to dura). Neuronal recordings were made using a multielectrode recording system (Plexon). To determine whether avBST neurons were modulated by prelimbic terminal photoillumination, we recorded with the following parameters: $0-15 \mathrm{~min}$, no laser on; $15-30 \mathrm{~min}, 473 \mathrm{~nm}$ laser pulsed at $20 \mathrm{~Hz}$ with $10 \%$ duty cycle; $30-45$ $\mathrm{min}, 561 \mathrm{~nm}$ laser on. The optrode was advanced ventrally by $0.3 \mathrm{~mm}$ three times for a total of four recordings. After the recording session, the hardware was removed and animals were prepared for histology (see Histology and tissue processing).

The Plexon Off-Line Sorter program was used for neuronal preprocessing. Principal component analysis (PCA) and waveform shape were used for spike sorting. Single units had (1) consistent waveforms (Heesch et al., 1995), (2) distinct clustering in PCA space, and (3) a refractory period of $<2 \mathrm{~ms}$. Analysis of neuronal activity was performed using custom routines in MATLAB.

\section{Histology and tissue processing}

Following experiments, rats were anesthetized with pentobarbital (Fatal Plus; $150 \mathrm{mg} / \mathrm{kg}$, i.p.) and then perfused with $100 \mathrm{ml} 0.9 \% \mathrm{NaCl}$, then 660 $\mathrm{ml}$ of ice-cold $4 \%$ paraformaldehyde (PFA) at a rate of $55 \mathrm{ml} / \mathrm{min}$. After harvesting, brains were postfixed in $4 \% \mathrm{PFA}$ at $4^{\circ} \mathrm{C}$ for $6 \mathrm{~h}$, then cryoprotected in $20 \%$ sucrose/ KPBS for $18 \mathrm{~h}$. Next, brains were frozen on dry ice, then $30 \mu \mathrm{m}$ sections were cut in a one-in-five series on a sliding microtome (Leica) and collected in cryoprotectant solution for storage at $-20^{\circ} \mathrm{C}$.

\section{Histochemistry}

Immunolocalization was performed on free-floating sections with primary antisera raised against BDA (mouse monoclonal, 1:1000; Jackson ImmunoResearch Laboratories), Fos (rabbit polyclonal, 1:1000; Santa Cruz Biotechnology), or CTb (goat polyclonal, 1:16,000; List Biological Laboratories) for tracer experiments or anti-GFP (rabbit polyclonal, 1:25,000; ThermoFisher) and glutamate decarboxylase (GAD)-65 (mouse monoclonal, 1:100; Iowa Developmental Studies Hybridoma Bank; Chang and Gottlieb, 1988) for optogenetic and pathway characterization experiments. Labeling was visualized with secondary antibodies diluted 1:500, including AlexaFluor 546 (donkey anti-goat; ThermoFisher), AlexaFluor 488 (goat anti-rabbit; ThermoFisher), and AlexaFluor 633 (goat anti-mouse, ThermoFisher). Finally, Fos labeling was amplified with a biotinylated goat anti-rabbit secondary antibody and streptavidin-conjugated AlexaFluor 633 (ThermoFisher). FG was visualized with native fluorescence.

The antibodies for BDA, CTb, and GFP are raised against exogenous substances used for neuroanatomical tract tracing. Thus, specificity is easily verified by showing an absence of immunostaining in brain tissue not containing the tracer. These antibodies have also been used and published widely. For the Fos antibody, we have validated that it recognizes a band of the appropriate molecular weight in immunoblotting experiments (unpublished) and yields a histochemical profile consistent with other commercially available Fos antibodies. This antibody has been widely used for immunohistochemical analysis of functional activation in rodent brain sections (Krause et al., 2011; Ramirez et al., 2015). The GAD-65 antibody has been previously characterized and validated using histochemical and biochemical approaches (Chang and Gottlieb, 1988; Escalpez et al., 1993).

\section{Quantitative histological analyses}

Fos-immunoreactive (Fos-ir) nuclei were quantified with stereological methods. Every fifth coronal section spanning mPFC underwent Fos immunohistochemical staining as described above. After mounting sections, an observer blinded to behavioral results counted Fos-ir nuclei, as well as Fos-ir within cells labeled by Fluoro-Gold, in three sections representing the typical spread of AAV or tracer microinjections (see Fig. 3).

\section{Data analyses and statistics}

No a priori criteria were used in how rats were allocated into treatment groups. Our determination of sample size is based upon our previously published work examining these same dependent measures, techniques, and experimental designs. Rats were excluded from the experiment only if injections or implants were off-target or if they did not show adequate weight gain and health (as judged by our on-site veterinarian). This accounted for an overall attrition rate of $10 \%$, relative to the final $N$ values reported in the text. Experimenters were generally unaware of the specific treatment group of each rat during data collection, except in cases where it was necessary to execute the correct procedure (e.g., whether to use 473 or $561 \mathrm{~nm}$ laser stimulation). All data analyses were performed by an experimenter unaware of the specific treatment group.

HPA data were analyzed with two-way repeated-measures ANOVA (Celada et al., 2001) where time served as a within-subjects comparison and virus as a between-group factor, followed by pairwise post hoc comparisons at specific time-points using an unpaired $t$ test (because there were only two groups involved). Student's $t$ test or one-way ANOVA were used for comparisons made between two and three groups, respectively, to assess differences in behavioral measures in both tail suspension and shock probe defensive burying tests. Following one-way ANOVA, post hoc pairwise comparisons between opsin (Halo or ChR2) and con- 
trol virus (YFP) using a Bonferroni correction. Finally, Fos cell counts and behavior were analyzed with linear regression.

\section{Results}

\section{Characterization of the} $\mathrm{PL} \rightarrow$ avBST pathway

In an initial experiment we microinjected the rostral PL subfield of the MPFC with adeno-associated viruses (AAV5) expressing either the inhibitory opsin eNpHR3.0 (Halo; Han and Boyden, 2007), excitatory channelrhodopsin (ChR2; Boyden et al., 2005), or YFP control virus under the CaMKII $\alpha$ promoter in adult male rats. These injections were targeted to produce expression in deep-layer glutamatergic projection neurons (Fig. 1a) that innervate targets including the avBST (Fig. 1b), which we and others have previously implicated in stress modulation (Herman et al., 1994; Choi et al., 2008; Crestani et al., 2013; Johnson et al., 2016). The placement and extent of viral expression patterns in rostral PL were evaluated with reference to past work describing the cytoarchitectonic parcellations of this and adjacent-lying cortical regions (Krettek and Price, 1977; Vogt and Peters, 1981; Radley et al., 2006; Van de Werd and Uylings, 2008). Lamination patterns distinguishing the major features of $\mathrm{mPFC}$ subfields was enabled by inspection of YFP expression in CaMKII $\alpha$-expressing neurons within and around the sites of injection (Fig. 1a). Because PL is considerably larger than infralimbic cortex (IL), it occupies a broader swath of the medial wall from the caudal end of IL and extends rostrally beyond IL to the tip of the frontal pole. For evaluation of injection sites in rostral-caudal regions encompassing both PL and IL, minimal spread of virus was noted to occur at the ventral boundary of PL into IL, as its indistinct lamination pattern (i.e., marked by an irregular border between layers I and II) make it readily distinguishable from PL. In cases exhibiting more rostral injection placements in PL, IL was absent, and the dorsal-ventral extent of PL was large enough that viral expression patterns were completely circumscribed within this subfield.

Further verification of injection site accuracy was provided by consideration of efferent projections from mPFC subregions. Although IL has been typically regarded as unique from other $\mathrm{mPFC}$ regions in its innervation of avBST (Vertes, 2004), past work of ours and others suggest that more rostral aspects of PL also provide at least a moderate degree of innervation in avBST in the rat (Sesack et al., 1989; Radley et al., 2009, 2013) and macaque (Chiba et al., 2001). As noted previously (Radley et al., 2009) viral injection placements in PL produced reli-
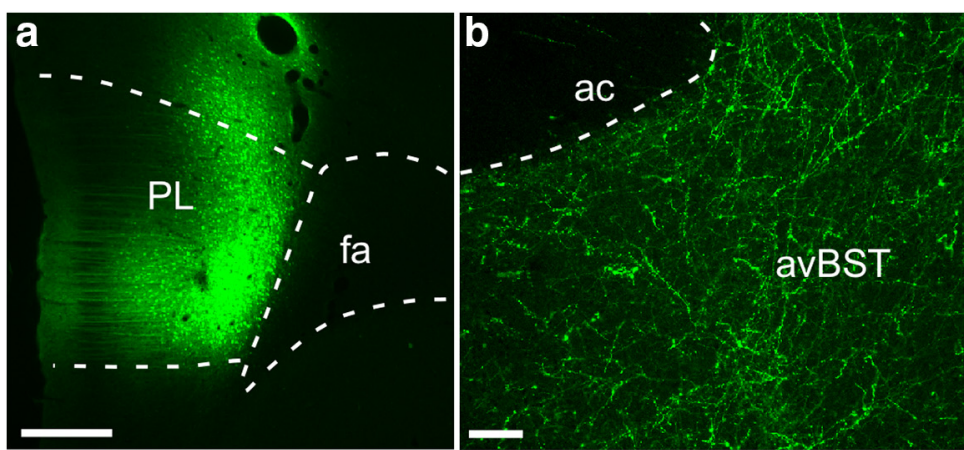

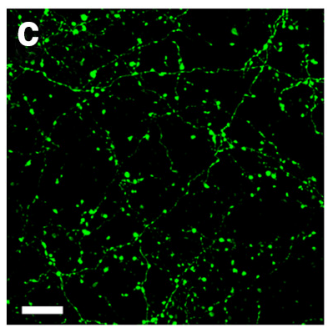

f

h
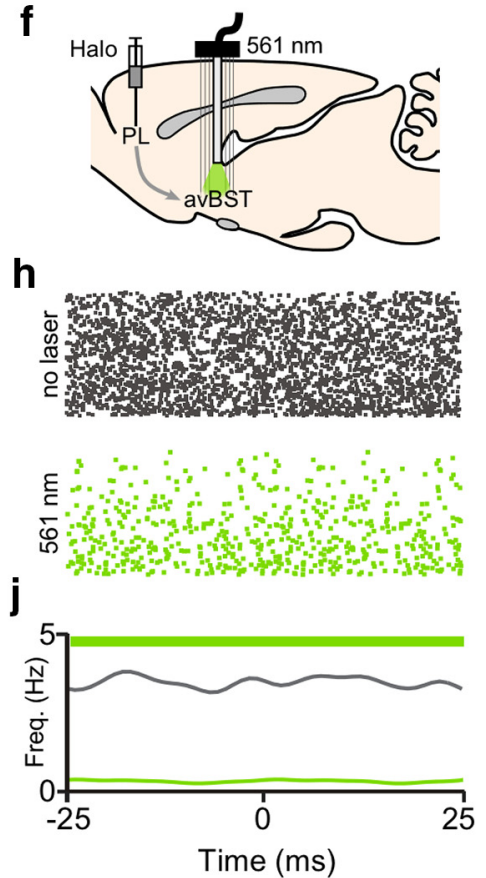

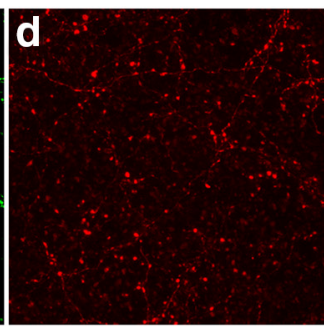

g

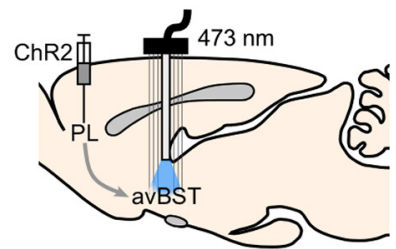

i
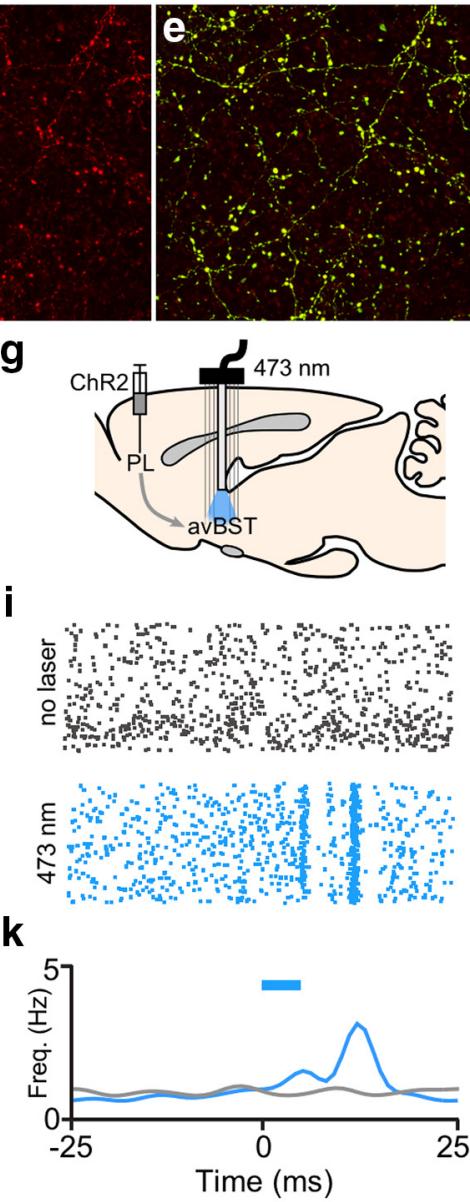

Figure 1. Characterization of the PL $\rightarrow$ avBST pathway. Representative image of AAV injection site $(\boldsymbol{a})$ and $\mathrm{YFP}$ expression in $\mathrm{PL}$ projection neurons. Scale bar, $500 \mu \mathrm{m}$. $\boldsymbol{b}$, YFP-expressing PL terminal fields within avBST. Scale bar, $100 \mu \mathrm{m}$. c, Confocal fluorescent image of avBST region containing dense YFP-immunoreactive axon fibers and terminals that originate from PL projection neurons following AAV injection in that cortical region d, Confocal fluorescent image from the same region as c showing immunoreactivity for the VGLUT1 in aVBST. $\boldsymbol{e}$, Composite image of overlapping puncta from the preceding panels. Scale bar: (in $\mathbf{c}) \boldsymbol{c}-\boldsymbol{e}$, $10 \mu \mathrm{m}$. Circuit schematic depicting viral injection site in PL and postsynaptic avBST recording during PL terminal field inhibition ( $\boldsymbol{f}$, Halo, green) and excitation ( $\boldsymbol{g}$, ChR2, blue). $\boldsymbol{h}$, Raster plot of action potentials in the absence (top, gray) and presence (bottom, green) of constant $561 \mathrm{~nm}$ light. $\boldsymbol{i}$, Raster plot of action potentials in the absence (top, gray) and presence (bottom, blue) of $20 \mathrm{~Hz}$ pulses of $473 \mathrm{~nm}$ light. $\boldsymbol{j}$, Summary histogram of data shown in $\boldsymbol{h}$, indicating that $561 \mathrm{~nm}$ illumination (green bar) of Haloexpressing PL terminals decreased avBST unit activity (green line) relative to the no laser condition (gray line). $\boldsymbol{k}$, Summary histogram of data shown in $\boldsymbol{i}$, indicating that $20 \mathrm{~Hz}, 5 \mathrm{~ms}$ pulses of $473 \mathrm{~nm}$ light (blue bar) of ChR2-expressing PL terminals increased avBST unit activity (blue line) relative to the no-laser condition (gray line).

able labeling of axonal terminal fields in avBST in a topographical manner, with more dorsal and caudally-placed injections giving rise to sparse-to-moderate innervation, and ventral and rostral injection placements yielding moderate-to-dense innervation, of avBST (Fig. 1b).

YFP-positive puncta were found to be immunoreactive for vesicular glutamate transporter 1 (VGLUT1; Fig. $1 c-e$ ), consis- 
a

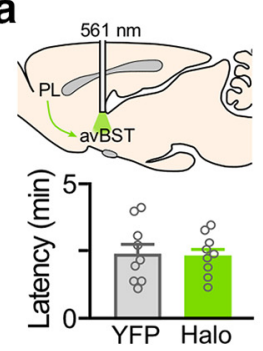

e

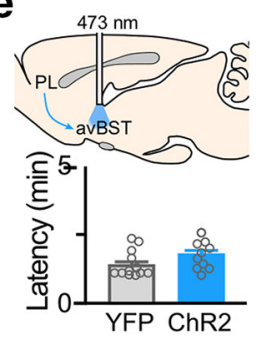

b

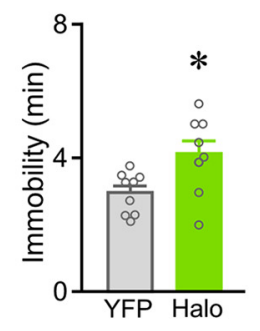

f

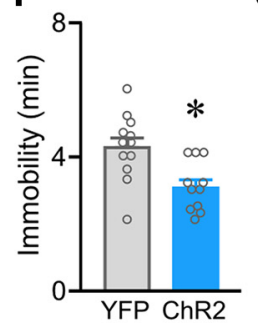

C

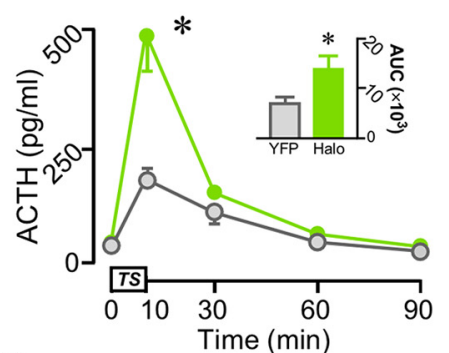

g

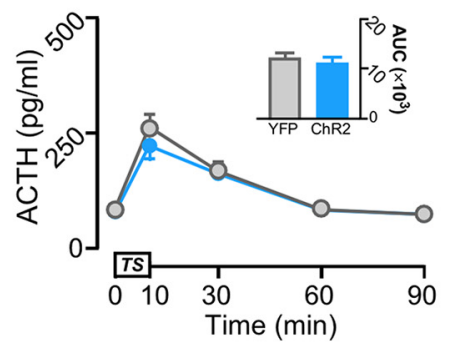

d

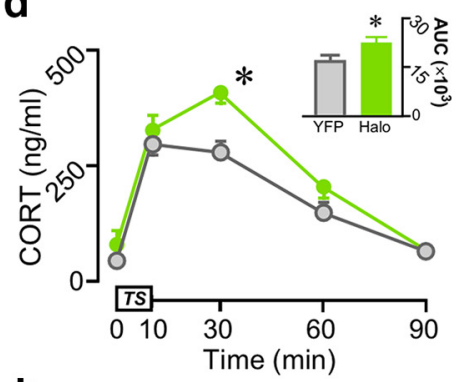

h

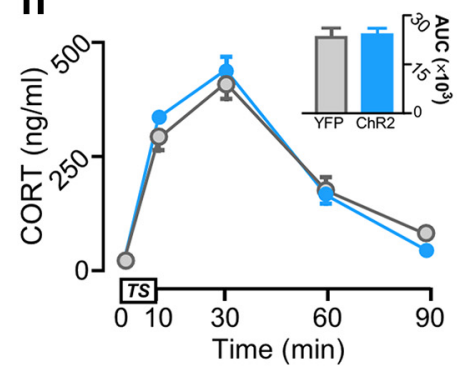

Figure 2. The PL $\rightarrow$ avBST pathway coordinates behavioral immobility and HPA axis inhibition during inescapable stress. Diagram depicting AAV microinjection into PL and fiber optic placement above avBST ( $\boldsymbol{a}$, top) to assess PL $\rightarrow$ avBST pathway involvement in responses to $10 \mathrm{~min}$ TS stress. PL $\rightarrow$ avBST pathway inhibition did not affect latency to first bout of immobility ( $\boldsymbol{a}$, bottom). However, the Halo group exhibited increased immobility duration $(\boldsymbol{b})$, as well as elevated ACTH (c), and CORT (d) levels relative to the YFP control group. $\boldsymbol{c}, \boldsymbol{d}$, Insets, Integrated ACTH and CORT responses (AUC) were also significantly increased in the Halo versus YFP group. $\boldsymbol{e}$, Latency to immobility was unchanged, while immobility duration was significantly lower in rats receiving $\mathrm{PL} \rightarrow \mathrm{avBST}$ pathway activation with ChR2 compared with YFP control group $(\boldsymbol{f})$. $\boldsymbol{g}$, Serial and integrated (AUC, inset) ACTH $(\boldsymbol{g})$ and CORT (h) levels did not differ between the ChR2 and YFP groups. Data are shown as mean \pm SEM. ${ }^{*} p<0.05$.

tent with localization of viral expression to glutamatergic pyramidal neurons in PL. To assess the postsynaptic effects of $\mathrm{PL} \rightarrow$ avBST optogenetic manipulations, rats received PL microinjections of AAVs expressing either Halo or ChR2. More than 4 weeks later, optrode recordings were performed both before and during laser illumination (Fig. $1 f, g$ ). Pathway photoinhibition by Halo significantly diminished avBST spiking, indicating that PL fibers are necessary for avBST activity (Fig. $1 h, j$ ). Photoexcitation by ChR2 produced short-latency postsynaptic responses, demonstrating that $20 \mathrm{~Hz}$ stimulation of PL fibers is capable of driving avBST activity in vivo (Fig. $1 i, k$ ).

\section{Optogenetic manipulation of the $\mathrm{PL} \rightarrow$ avBST pathway modulates a passive response set during inescapable stress} Previous studies using pharmacological and lesioning approaches suggest that the $\mathrm{mPFC}$ imparts inhibitory control over HPA activation during acute stress exposure (Diorio et al., 1993; Figueiredo et al., 2003; Radley et al., 2006; Weinberg et al., 2010), and past work suggests that this regulation could be mediated, at least in part, through input to BST (Radley et al., 2009, 2013; Yu and Sharp, 2012; Myers et al., 2014), which in turn has been shown to project to PVH (Cullinan et al., 1993; Dong et al., 2001; Dong and Swanson, 2006). Using AAV5 under the control of the CaMKII $\alpha$ promoter, we transduced PL pyramidal neurons with Halo or ChR2 fused to YFP, or with the same viral vector carrying only YFP. To activate or inhibit PL axon terminals in avBST, we implanted optical fibers bilaterally above avBST to deliver light $(20 \mathrm{~Hz}, 473 \mathrm{~nm}$ for ChR2, $561 \mathrm{~nm}$ for Halo) to avBST during a $10 \mathrm{~min}$ period of exposure to tail suspension. Our use of this simple behavioral assay is to provide an expedient means for evaluating behavioral activity during concurrent repeated blood sampling for the assessment of HPA activation (Johnson et al., 2016).

In the first of a two-part experiment, photoinhibition of the $\mathrm{PL} \rightarrow$ avBST pathway in the Halo group during 10 min of tail suspension significantly increased immobility behavior and augmented the pituitary-adrenal response profile compared with YFP controls that received the same $561 \mathrm{~nm}$ laser stimulation. Pathway inhibition with Halo increased the overall duration of immobility by $38 \%(t=2.68, \mathrm{df}=16, p=0.017)$, although had no effect on the latency to the first bout of immobility $(t=0.16$, $\mathrm{df}=16, p=0.87$; Fig. $2 a, b)$. Radioimmunoassay of plasma levels of ACTH and CORT revealed stress-induced increases in each hormone in both groups, although rats receiving Halo inactivation displayed an even greater enhancement in these indices than did YFP controls. For ACTH, there was an interaction between pathway inhibition with Halo and time $\left(F_{(4,56)}=6.50, p=\right.$ $0.0002)$, main effects of Halo $\left(F_{(1,14)}=7.98, p=0.014\right)$ and time $\left(F_{(4,56)}=24.8, p<0.0001\right)$. The Halo group displayed a $89 \%$ increase in the integrated ACTH response [area under curve (AUC); $t=2.72, \mathrm{df}=14, p=0.017]$ and a $174 \%$ increase at the 10 min time point $(t=5.81, \mathrm{df}=14 p<0.0001)$ relative to YFP controls (Fig. $2 c$ ). Analysis of plasma CORT revealed an interaction between Halo inhibition and time $\left(F_{(4,56)}=2.88, p=0.031\right)$, main effects of Halo $\left(F_{(1,14)}=7.27, p=0.017\right)$, and time $\left(F_{(4,56)}=\right.$ $86.03, p<0.0001)$. Halo rats also exhibited a $37 \%$ increase in the integrated CORT response (AUC; $t=3.12$, df $=14, p=0.008$ ) and $49 \%$ increase at the $30 \mathrm{~min}$ time point $(t=4.04, \mathrm{df}=14, p=$ 0.0001 ) compared with YFP control rats (Fig. $2 d$ ).

In the second part of this experiment, the effects of photostimulation of the $\mathrm{PL} \rightarrow$ avBST pathway using ChR2 throughout the $10 \mathrm{~min}$ tail suspension challenge was compared with YFP control rats receiving the same $473 \mathrm{~nm}$ light stimulation. Pathway activation with ChR2 significantly decreased immobility by $38 \%$ $(t=3.20, \mathrm{df}=21, p=0.004)$ compared with the response in the YFP controls (Fig. 2e,f). However, activation of this pathway failed to significantly attenuate any measure of pituitary-adrenal responses (Fig. $2 g, h$; ACTH virus by time interaction: $F_{(4,84)}=$ $0.90, p=0.47$; CORT virus by time interaction: $F_{(4,84)}=1.37, p=$ $0.25)$. Together, the photoinhibition and excitation data indicate 
that $\mathrm{PL} \rightarrow$ avBST pathway activity is capable of bidirectionally modulating behavioral immobility during tail suspension (TS). However, only pathway inhibition had the ability to augment HPA output during and following TS, suggesting that $\mathrm{PL}$ activity plays a permissive role in modulating HPA activation during inescapable challenges.

\section{Divergence of $\mathrm{PL} \rightarrow$ avBST pathway toward PVH and ventrolateral PAG}

A previous report of ours suggests that stress-induced behavioral immobility and HPA activation may be supported by respective divergent pathways involving avBST input to the ventrolateral PAG or PVH. We next sought to address whether PL influences on these stress response features may be supported by respective disynaptic pathways involving $\mathrm{PL} \rightarrow$ avBST $\rightarrow$ $\mathrm{PVH}$ or $\mathrm{PL} \rightarrow$ avBST $\rightarrow$ ventrolateral PAG. Pressure injections of the anterograde tracer, $\mathrm{BDA}$, were placed into $\mathrm{PL}$ in combination with FG injections in either PVH $(n=4)$ or ventrolateral PAG $(n=4$; Fig. 3). Histochemical visualization of transported BDA revealed an array of labeled axonal fibers and varicosities throughout subdivisions of avBST and adjacent parastrial nucleus, implicated in the inhibitory modulation of HPA output (Johnson et al., 2016). We and others have noted that PL does not directly innervate PVH proper (Sesack et al., 1989; Vertes, 2004; Radley et al., 2009), although it issues direct input to ventrolateral PAG (Floyd et al., 2000). Confocal laser-scanning microscope (LSM) analysis in avBST revealed frequent instances of close appositions between labeled axonal elements from $\mathrm{PL}$ and $\mathrm{PVH}$-projecting or ventrolateral PAG-projecting neurons (Fig. $4 a, b$ ).

We next considered whether divergent projections from avBST to PVH and ventrolateral PAG derive from a single, or separate, cell population. To address this possibility, we pressure injected the retrograde tracers, CTB and FG in ventrolateral PAG and $\mathrm{PVH}$, respectively. Analysis of the overlap of retrogradelylabeled neurons in avBST revealed an extensive intermingling of neurons projecting to each target (Fig. $4 c$ ). However, confocal LSM analysis failed to reveal any dual localization of CTB and FG in single avBST neurons. PVH-projecting somata were clustered within the dorsomedial and fusiform subdivisions (according to the BST nomenclature of Dong et al., 2001), parastrial nucleus (Loewy and McKellar, 1980; Swanson and Sawchenko, 1983; Moga and Saper, 1994) and also displayed a nominal amount of scattering in other avBST compartments. Whereas ventrolateral PAG-projecting neurons also displayed some clustering in and around the fusiform subdivision, in general this subpopulation exhibited a more widespread scattered distribution throughout the entire extent of avBST.

Previous histochemical analyses of avBST at-large, and the pathways under scrutiny indicate a GABAergic inhibitory role in their modulation of stress response features (Cullinan et al., 1993; Poulin et al., 2009; Radley and Sawchenko, 2011, 2015; Kudo et al., 2012; Johnson et al., 2016). We verified this in rats that receiving avBST injections of AAV5, under the control of the human synapsin promoter, carrying only YFP (Fig. $5 a-d$ ). Confocal LSM analyses of terminal fields in PVH and ventrolateral PAG revealed extensive immunolocalization of YFP-labeled puncta with GAD65 (Fig. 5e-j), consistent with our previous analyses that $>80 \%$ of these inputs are GABAergic (Johnson et al., 2016). In addition, many of the dual-labeled YFP and GAD puncta in in the neurosecretory, medial parvicellular zone of the PVH resided in close apposition with CRF-immunoreactive neurons (Fig. $5 g$ ). These studies show that avBST provides a significant substrate for PL terminal fields intermingling with distinct subpopulations of cells, that in turn issue divergent GABAergic projections to downstream effector regions capable of modulating PVH (HPA output) and ventrolateral PAG (immobility) during stress.

\section{Activation of $\mathrm{PL} \rightarrow$ avBST pathway is inversely correlated with passive coping}

The foregoing experiments demonstrate that activity in the $\mathrm{PL} \rightarrow$ avBST pathway provides an important restraining influence over HPA output and behavioral immobility. Nevertheless, it remains uncertain as to whether this circuit is capable of inhibiting immobility, engaging active behaviors, or some combination thereof. Insight into resolving this matter can be gleaned from past work in the stress field implicating "response patterns", whereby rodents exhibiting enhanced HPA reactivity also show a propensity toward behavioral passivity (i.e., immobility) during environmental threats evaluated as uncontrollable or inescapable (Mason, 1975; Henry, 1992; Koolhaas, 2008). From a circuit perspective, the fact that activation of the ventrolateral PAG alone is capable of evoking passive defensive behaviors (Keay and Bandler, 2001; Assareh et al., 2016), raises the possibility that activity in the PL $\rightarrow$ avBST pathway may inhibit the behavioral compo- 

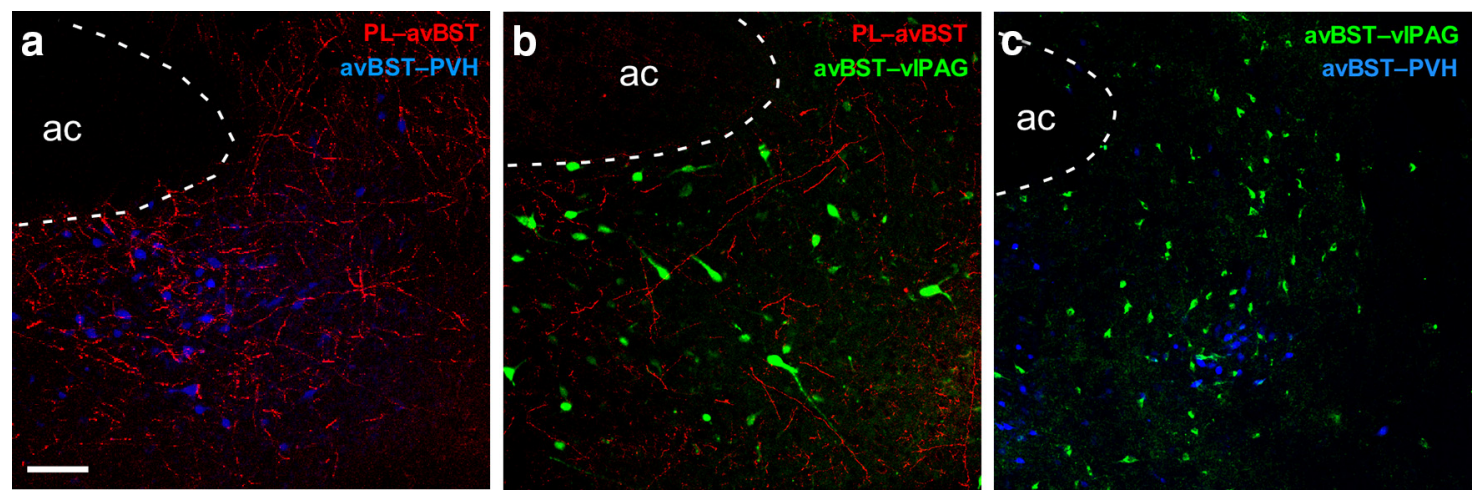

Figure 4. Anterograde and retrograde tract tracing of PL $\rightarrow$ avBST pathways. Experiments revealed that PL fibers terminate near avBST neurons that project to either the PVH ( $(\boldsymbol{a})$ or ventrolateral PAG (b). $\boldsymbol{c}$, A dual retrograde tracer experiment revealed that populations of PVH- and ventrolateral PAG-projecting avBST neurons do not display any overlap. Scale bar: (in $\boldsymbol{a}$ ) $\boldsymbol{a}-\boldsymbol{c}, 100 \mu \mathrm{m}$.
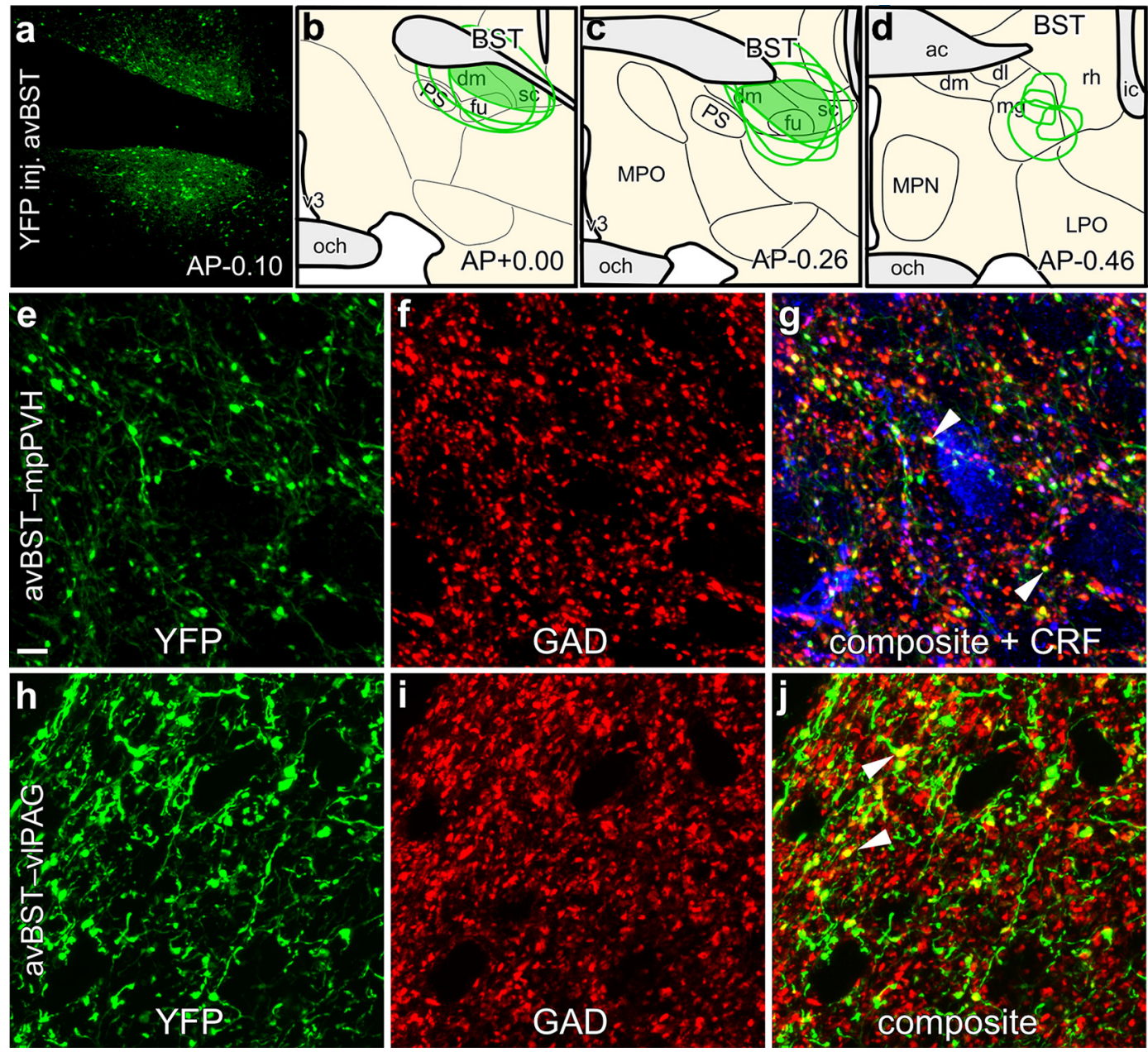

Figure 5. Evidence that avBST projections to PVH and ventrolateral PAG are GABAergic. $\boldsymbol{a}$, Confocal fluorescent image showing an example of YFP expression after injection of AAV5 centered in avBST. $\boldsymbol{b}-\boldsymbol{d}$, Green shaded regions in avBST indicate areas of overlap common to all tracer injections $(N=4)$ and their approximate extent of diffusion into adjacent structures. ac, Anterior commissure; dl, dorsolateral subdivision of the avBST; dm, dorsomedial subdivision of the avBST; fu, fusiform subdivision of the avBST; ic, internal capsule; LP0, lateral preoptic area; mg, magnocellular subdivision of the posterior BST; MPN, median preoptic nucleus; MPO, medial preoptic area; och, optic chiasm; PS, parastrial nucleus; rh, rhomboid subdivision of the posterior BST; V3, third ventricle. Scale bars: $\boldsymbol{a}, 300 \mu \mathrm{m} ; \boldsymbol{b}-\boldsymbol{d}, 400 \mu \mathrm{m}$. $\boldsymbol{e}$, Confocal fluorescent images depict immunoreactivity YFP in the medial parvocellular subdivision (mp) of PVH following AAV injection in avBST, and the $65 \mathrm{kDa}$ form of GAD, a synthetic enzyme for GABA (f). $\boldsymbol{g}$, Composite image of images in $\boldsymbol{e}$ and $\boldsymbol{f}$, with immunolocalization with (RF (blue somata). Numerous instances of YFP $+/$ $G A D+$ puncta were noted to make appositions with (RF-labeled neurons (arrowheads). $\boldsymbol{h}$, In ventrolateral PAG, YFP-immunolabeled terminals are also abundant following AAV injection in avBST. Extensive colocalization between YFP and GAD-65 $(\boldsymbol{i}, \boldsymbol{j})$ was noted in this region as well (arrowheads). Scale bar: (in $\boldsymbol{e}) \boldsymbol{e}-\boldsymbol{j}, 5 \mu \mathrm{m}$.

nent of a passive response set via activation of ventrolateral PAGprojecting GABAergic neurons in avBST.

To address the $\mathrm{PL} \rightarrow$ avBST pathway involvement in active versus passive stress coping behavior, we initially subjected groups of rats bearing retrograde tracer injections in avBST to the shock probe defensive burying test (Treit et al., 1981; De Boer and Koolhaas, 2003). In this paradigm, an electrified shock probe is inserted into the cage and rats receive a $2 \mathrm{~mA}$ shock upon first 

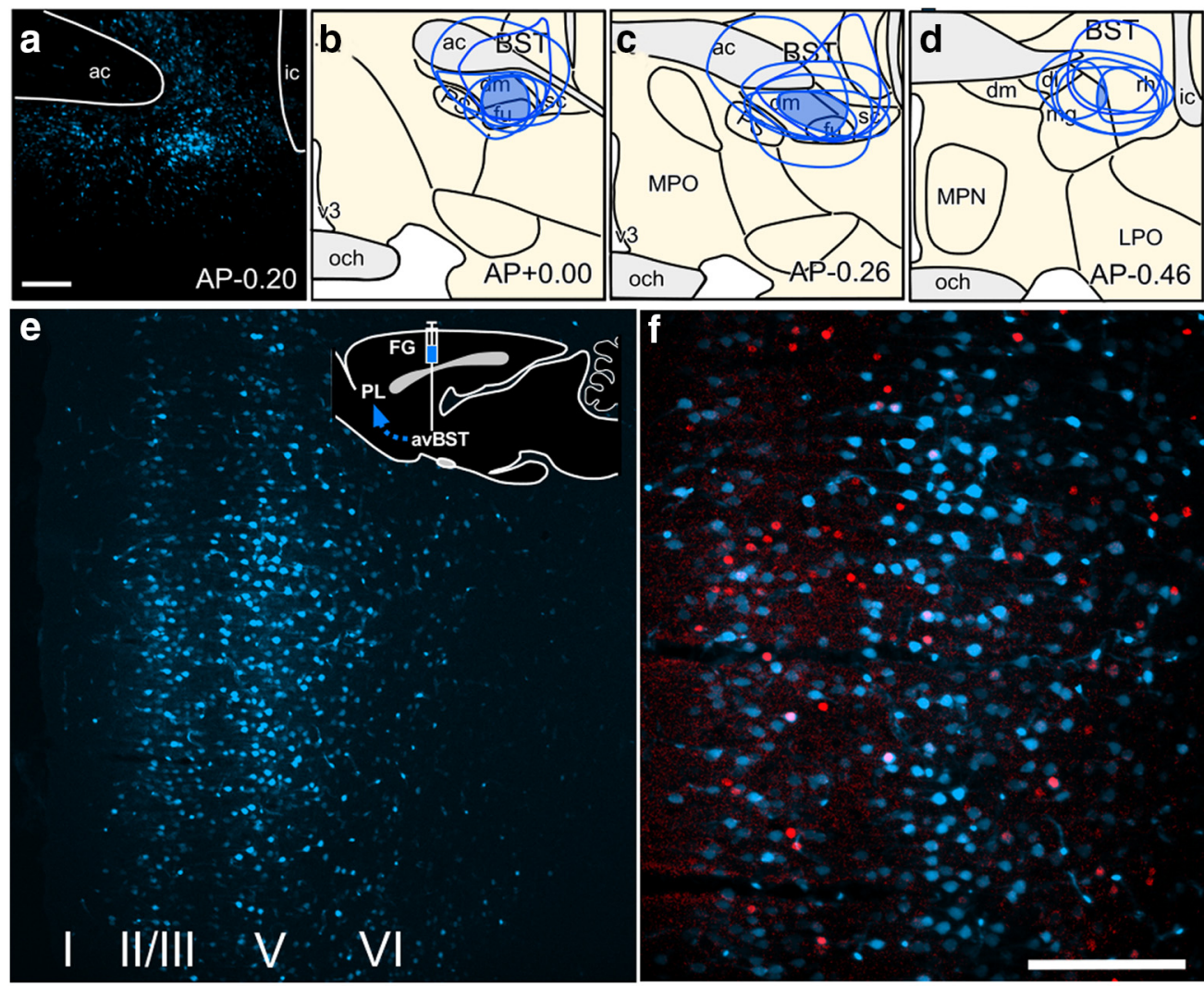

g

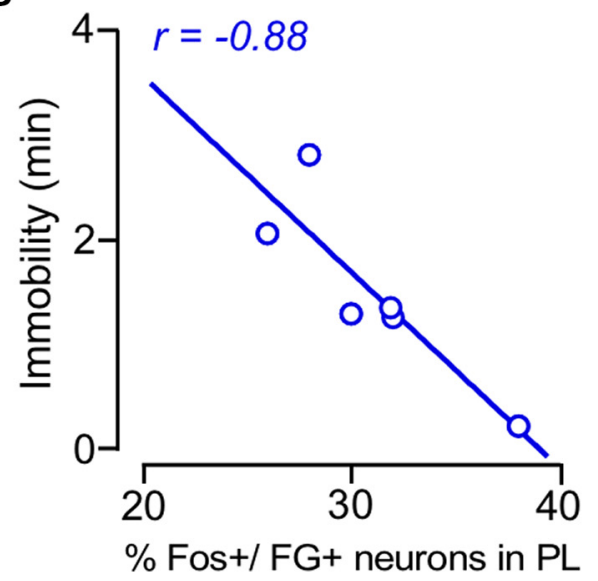

h

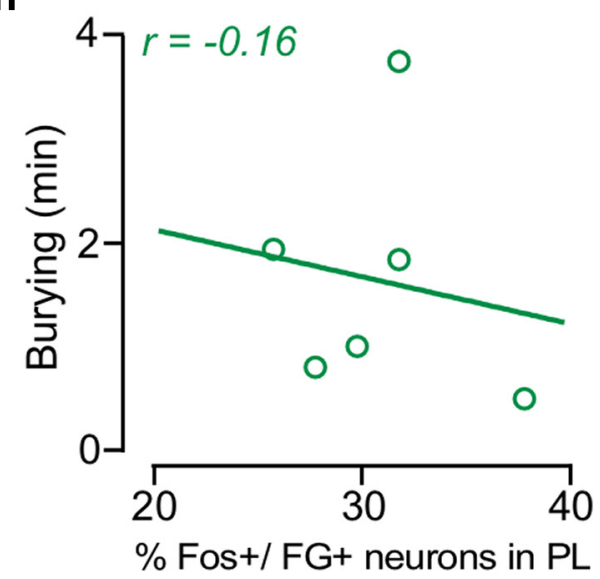

Figure 6. $\quad \mathrm{PL} \rightarrow \mathrm{avBST}$ pathway involvement in passive coping behavior. $\boldsymbol{a}$, Confocal fluorescent image of an example tracer placement in avBST. $\boldsymbol{b}-\boldsymbol{d}$, Blue shaded regions in avBST indicate areas of overlap common to all tracer injections $(N=6)$ and their approximate extent of diffusion into adjacent structures. ac, Anterior commissure; dl, dorsolateral subdivision of the avBST; dm, dorsomedial subdivision of the avBST; fu, fusiform subdivision of the avBST; ic, internal capsule; LPO, lateral preoptic area; $\mathrm{mg}$, magnocellular subdivision of the posterior BST; MPN, median preoptic nucleus; MPO, medial preoptic area; och, optic chiasm; PS, parastrial nucleus; rh, rhomboid subdivision of the posterior BST; v3, third ventricle. Scale bars: $\boldsymbol{a}, 300 \mu \mathrm{m} ; \boldsymbol{b}-\boldsymbol{d}, 400 \mu \mathrm{m}$. Rats in $\boldsymbol{e}-\boldsymbol{h}$ were subjected to the shock probe defensive burying test for $10 \mathrm{~min}$ and perfused $90 \mathrm{~min}$ thereafter. $\boldsymbol{e}$, Inset, Schematic diagram of Fluoro-gold injection site in avBST with arrow indicating retrograde transport of tracer to PL. Retrogradely labeled neurons in PL are displayed in blue and Fos-immunoreactive nuclei in red. Scale bar: (in $\boldsymbol{f}$ ) $\boldsymbol{e}, \boldsymbol{f}, 100 \mu \mathrm{m}$. The number of Fos immunolocalizations in retrogradely labeled PL neurons correlated with the length of time immobile $(\boldsymbol{g})$ but not with the extent of burying behavior $(\boldsymbol{h})$.

contact. Following the shock, rats display a repertoire of behavioral responses, typified by the probe-directed burying of cage bedding material (active coping) and time spent freezing/ immobile (passive coping; De Boer and Koolhaas, 2003). Behaviors were scored over a 10 min period following shock in rats bearing retrograde tracer injections in avBST (Fig. $6 a-d$ ), and behaviors were correlated with Fos immediate-early gene activation in avBST-projecting PL neurons (Fig. 6e,f). Quantitative analyses revealed a negative correlation between immobility and the number of colabeled Fos and FG neurons in PL (Fig. $6 g ; R^{2}=$ $\left.0.77, F_{(1,4)}=13.65, p=0.021\right)$. By contrast, no correlation was observed with respect to burying behavior relative to the number of neurons in PL bearing dual localization with Fos and FG (Fig. $6 h ; R^{2}=0.027, F_{(1,4)}=0.11, p=0.76$ ). Moreover, quantitative analysis of Fos-immunolabeled nuclei alone in PL failed to reveal any general relationship between the level of activation in PL and immobility $\left(R^{2}=0.14\right)$ or burying $\left(R^{2}=\right.$ $0.28)$. This correlation suggests a bias of activity in the $\mathrm{PL} \rightarrow$ avBST pathway in the regulation of passive over active behavioral responses. 
a

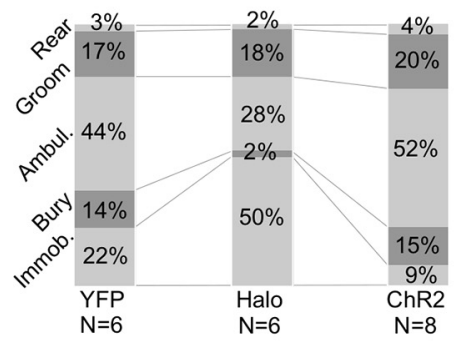

C

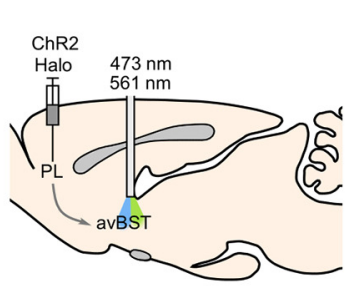

d

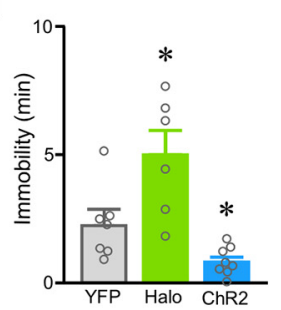

b

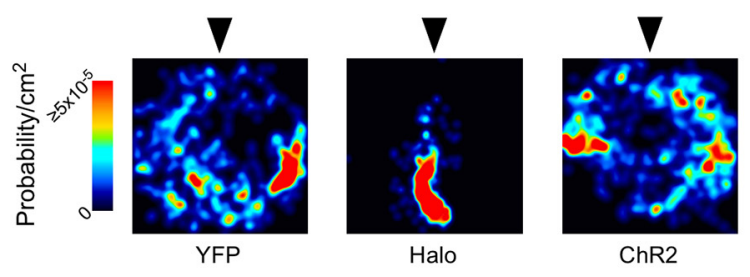

e

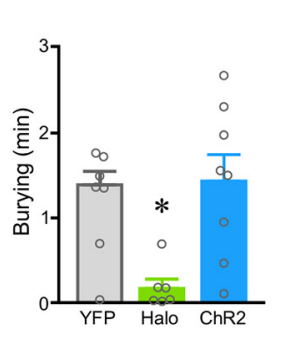

f
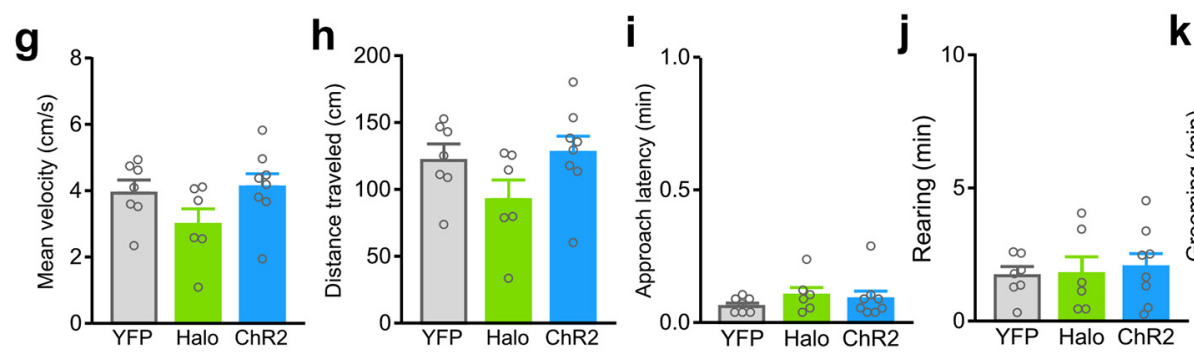

k

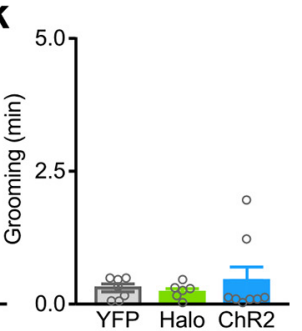

Figure 7. Activity in the PL $\rightarrow$ aVBST pathway bidirectionally modulates passive coping behavior. $\boldsymbol{a}$, Stacked histograms display the average amount of time that rats in each treatment group spent engaging in different behaviors in the shock probe defensive burying test (SPDB) over the 10 min period following shock. Each column displays average percentages for each category of scored behavior during concurrent laser stimulation of the PL $\rightarrow$ avBST pathway in YFP control, Halo (inhibition), and ChR2 (activation) groups. $\boldsymbol{b}$, Heat maps indicate the time spent within the arena over a 10 min period following exposure to shock (probe is indicated by the arrowhead) in a representative example from each treatment group. c, lllustration of AAV-Halo or ChR2 injection into PL and fiber placement above avBST for pathway inhibition or activation during SPDB. $\boldsymbol{d}$, During the defensive burying test, rats receiving inactivation with Halo exhibited increased immobility (Immob) behavior, whereas pathway activation with ChR2 resulted in significantly less immobility than YFP controls. e, Burying was significantly decreased in the Halo group, but unchanged in ChR2 animals. $\boldsymbol{f}$, Ambulation (Ambul) was decreased in the Halo group, likely a reflection of increased immobility. During the initial $30 \mathrm{~s}$ bout of ambulation following shock, no group differences were observed for either velocity $(\boldsymbol{g})$ or distance traveled $(\boldsymbol{h})$ in rats receiving photoinhibition with Halo or photoexcitation ChR2 of the PL $\rightarrow$ avBST pathway relative to laser-stimulated YFP control rats. No differences were noted in approach latency $(\boldsymbol{i})$, rearing $(\boldsymbol{b})$, or grooming $(\boldsymbol{k})$ behavior as a function of laser stimulation in either YFP, Halo, or ChR2 groups. Data are shown as mean + SEM. ${ }^{*} p<0.025$ (Bonferroni correction).

\section{Optogenetic manipulation of the PL $\rightarrow$ avBST pathway} bidirectionally modulates passive coping behavior Next, we examined the necessity of this pathway in the modulation passive coping behavior in the shock probe defensive burying test. Using AAV5 under the control of the CaMKII $\alpha$ promoter, we transduced PL pyramidal neurons with Halo or ChR2 fused to YFP, or with the same viral vector carrying only YFP. To activate or inhibit PL axon terminals in avBST, we implanted optical fibers bilaterally above avBST to deliver light to avBST $(20 \mathrm{~Hz}, 473 \mathrm{~nm}$ for ChR2; $561 \mathrm{~nm}$ for Halo; controls were counterbalanced so that half received $473 \mathrm{~nm}$ and half received $561 \mathrm{~nm}$ light). The $10 \mathrm{~min}$ laser stimulation and behavioral observation period was initiated immediately after rats approached and received a $2 \mathrm{~mA}$ shock from the electrified probe (Fig. $7 a-c$ ).

One-way ANOVA revealed main effects of opsin treatment on immobility $\left(F_{(2,18)}=13.21, p=0.0003\right)$ and burying $\left(F_{(2,18)}=6.27\right.$, $p=0.009)$. Photoinhibition of the PL $\rightarrow$ avBST pathway increased immobility by $124 \%(p=0.023)$, whereas photoexcitation decreased immobility by $64 \%(p=0.021)$, relative to YFP control rats (Fig. 7d). By contrast, whereas photoinhibition substantially decreased burying (by $86 \%, \mathrm{p} 0.0038$ ), photoexcitation failed to alter this index of active coping ( $p=0.57$; Fig. $7 e$ ). The lack of any bidirectional effect on burying is accountable by the fact that decreased burying by rats receiving $\mathrm{PL} \rightarrow$ avBST pathway inactivation is a secondary consequence to increased immobility, as rats receiving pathway photoexcitation exhibited decreased immobility that was not resultant in any increase in time spent burying.

There was an overall effect of opsin treatment on ambulation $\left(F_{(2,18)}=10.73, p=0.0009\right)$, however ambulation time was significantly decreased only in the Halo group (Halo vs YFP, $p=$ 0.0006 ; ChR2 vs YFP, $p=0.17$; Fig. $7 f$ ). No group differences were observed in locomotor activity (i.e., velocity, distance traveled; Fig. $7 g, h)$, nor did groups display any changes in other parameters of interest to suggest underlying variations in motor capacity, shock sensitivity, displacement, or exploratory behaviors (Fig. $7 i-k$ ).

In a parallel experiment, we examined the effects of $\mathrm{PL} \rightarrow$ avBST pathway inactivation using a different inhibitory opsin, the light-sensitive proton pump archaerhodopsin (Arch; Chow et al., 2010), on behavior in the shock probe defensive burying test. Using AAV5 under the control of the CaMKII $\alpha$ promoter, we transduced PL pyramidal neurons with Arch fused to YFP, or with the same viral vector carrying only YFP, and implanted optical fibers bilaterally above avBST to deliver 561 $\mathrm{nm}$ light to avBST. Photoinhibition of PL neuron axons in 

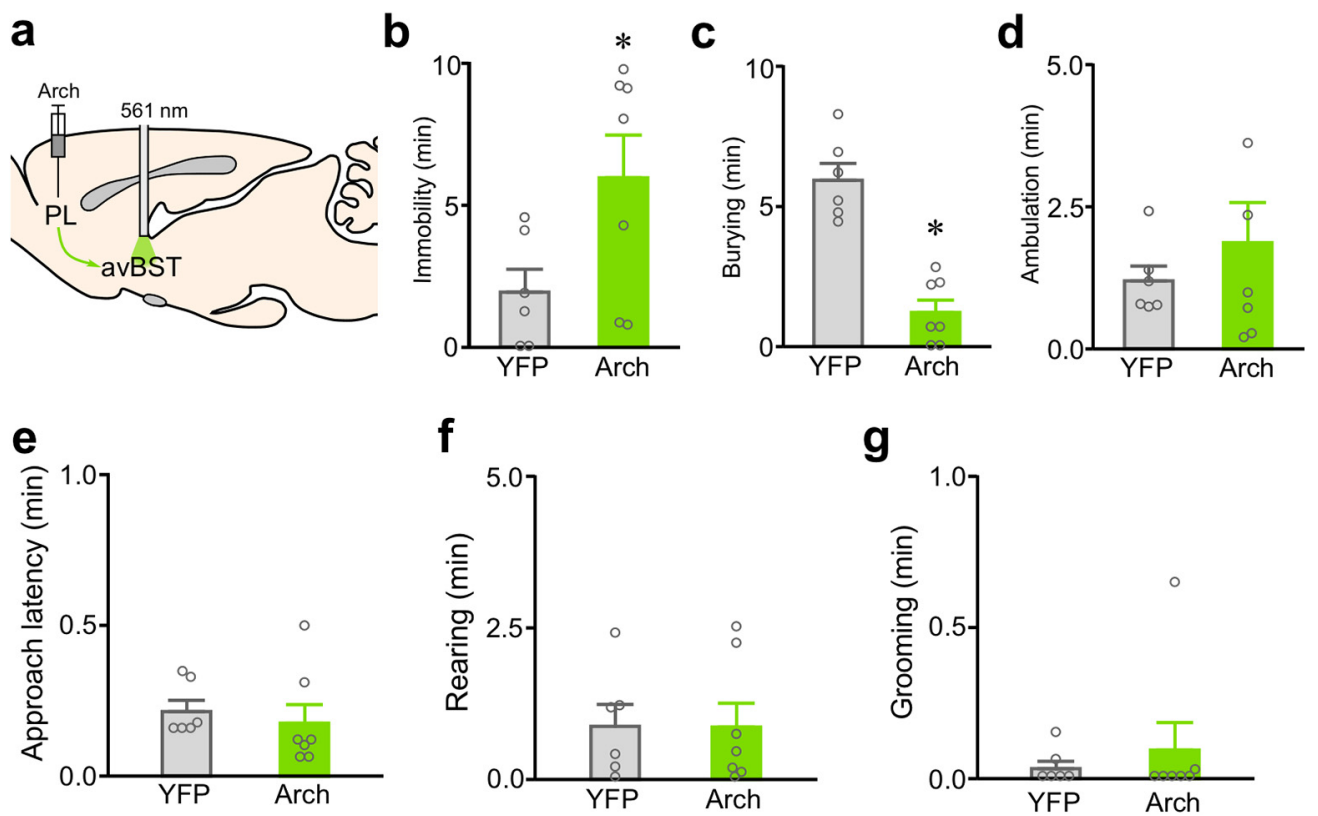

Figure 8. Inactivation of the PL $\rightarrow$ avBST pathway with a different inhibitory opsin (Arch) increases passive, and decreases active coping behaviors. $\boldsymbol{a}$, Illustration of AAV-Arch injection into PL and fiber placement above avBST for pathway inhibition during shock probe defensive burying test. Rats receiving inactivation with Arch exhibited increased immobility (b), and decreased burying behavior $(\boldsymbol{c}$ ), relative to laser-stimulated YFP rats. $\boldsymbol{d}$, Ancillary measures of ambulation $(\boldsymbol{d})$, approach latency $(\boldsymbol{e})$, rearing $(\boldsymbol{f})$, and grooming $(\boldsymbol{g})$ did not significantly differ as a function of experimental treatment. Data are shown as mean + SEM. ${ }^{*} p<0.05$.

a
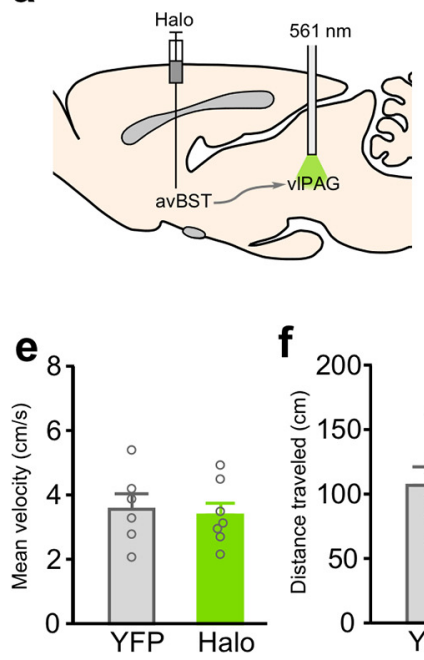

b
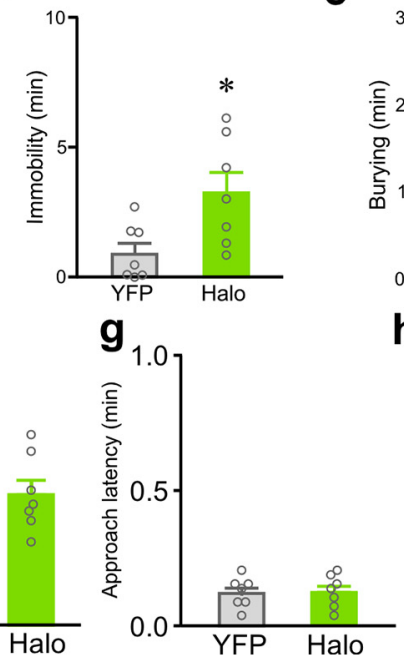

C

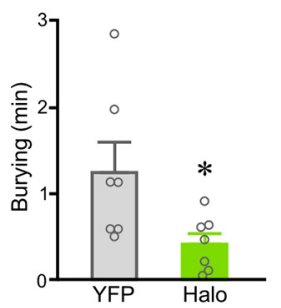

h

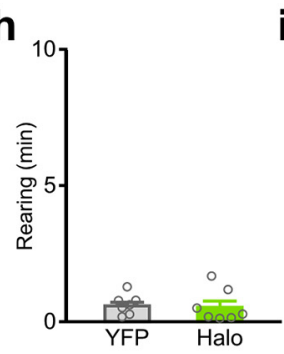

d

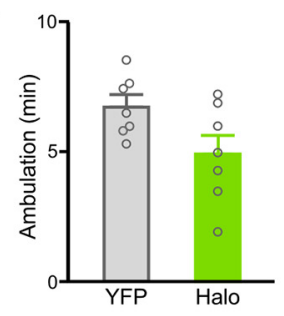

i

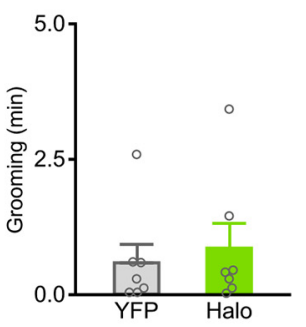

Figure 9. Activity in the avBST $\rightarrow$ ventrolateral PAG pathway is necessary for restraining passive coping responses. $\boldsymbol{a}$, Diagram of experiment involving AAV microinjection into avBST and illumination of its terminal fields within ventrolateral PAG for inhibition of this pathway during shock probe defensive burying test. Immobility was elevated (b), burying was decreased (c), and ambulation was unchanged (d) for Halo group compared with YFP controls. During the initial $30 \mathrm{~s}$ bout of ambulation following shock, no group differences were observed for either velocity (e) or distance traveled $(\boldsymbol{f})$ in rats receiving inhibition of the PL $\rightarrow$ avBST pathway. No differences were noted in approach latency $(\boldsymbol{g})$, rearing $(\boldsymbol{h})$, or grooming $(\boldsymbol{i})$ behavior as a function of laser stimulation in either YFP or Halo groups. Data are shown as mean + SEM. ${ }^{*} p<0.05$.

avBST produced a similar result to pathway inhibition with Halo, decreasing burying by $79 \%(t=6.51, \mathrm{df}=11, p<$ 0.0001 ) and increasing immobility (by $206 \% ; t=2.25, \mathrm{df}=$ $11, p=0.046$; Fig. 8).

\section{Photoinhibition of the downstream avBST $\rightarrow$ ventrolateral PAG pathway also increases passive coping behavior}

Previous work of ours showing that photoinhibition of the avB$\mathrm{ST} \rightarrow$ ventrolateral PAG pathway increases immobility in both tail suspension and forced swim test in rats (Johnson et al., 2016), is consistent with the present interpretation that the $\mathrm{PL} \rightarrow \mathrm{avBST}$ pathway modulates passive coping behavior. In a final experiment we addressed the possibility that these effects may be mediated through an avBST projection to the ventrolateral PAG. Rats were injected AAV5 under the control of the human synapsin promoter in avBST to transduce neurons with Halo fused to YFP, or injected the same viral vector carrying only YFP in a separate group (Fig. 9a). In the same procedure, optical fibers were implanted bilaterally above the ventrolateral PAG to deliver $561 \mathrm{~nm}$ light to this region in both Halo and YFP control groups during 


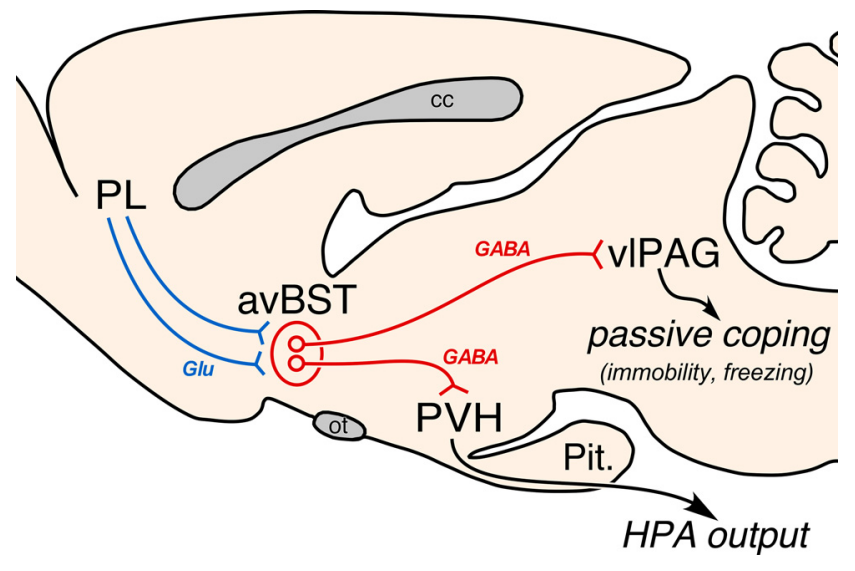

Figure 10. Summary diagram. Illustration of the PL $\rightarrow$ avBST pathway and its assembly of a passive coping response set. Axonal projections emanating from rostral PL contact distinct yet intermingled cell populations within avBST that, in turn, issue divergent GABAergic projections to either PVH or ventrolateral PAG. Photoinhibition and excitation of the PL $\rightarrow$ aVBST pathway bidirectionally modulated passive coping behavior via a downstream avBST $\rightarrow$ VIPAG pathway, whereas photoinhibition augmented HPA output - an effect mediated by a previously described avBST $\rightarrow$ PVH pathway (Johnson et al., 2016). cc, corpus callosum; glu, glutamate; ot, optic tract; pit., pituitary gland.

the 10 min observation period in the shock probe defensive burying test. Photo-inactivation of avBST axons in ventrolateral PAG with Halo significantly increased immobility (by 230\%, $p=$ 0.023 ), and decreased burying (by $67 \%, p=0.035$ ) relative to laser-stimulated YFP control rats (Fig. $9 b, c$ ). No changes were noted in ambulatory or locomotor activity, nor any other parameters of interest (Fig. 9d-i). Together, these findings lend support to the ventrolateral PAG as an important downstream effector of prefrontal inhibitory influences over passive coping responses during stressful experiences.

\section{Discussion}

Pituitary-adrenal output and behavioral immobility were both markedly exaggerated in response to photoinhibition of PL input to avBST concurrent with stressor exposure, whereas photoactivation of this pathway decreased behavioral immobility but failed to alter HPA indices. Tracing experiments confirmed that projections from pyramidal neurons in rostral PL innervate separate subpopulations of neurons within avBST that provide GABAergic input to the neurosecretory zone of the PVH and ventrolateral PAG. Photostimulation and inhibition of the PL $\rightarrow$ avBST pathway respectively increased and decreased passive coping (immobility) in the shock-probe defensive burying test, without having any direct effect on active coping (burying) behavior. In the final experiment, photoinhibition of avBST input to ventrolateral PAG increased passive coping behavior, closely recapitulating the effects of inactivating this pathway during other inescapable challenges as previously reported (Johnson et al., 2016). This study provides the first evidence for a mechanism involving differential activity in the PL $\rightarrow$ avBST pathway that biases the organism away from a passive response set, and may enable the engagement of circuits that promote active behaviors. By contrast, diminished activity in this circuit may enable a passive response set, such as during more protracted or inescapable challenges, especially in settings that disfavor rapid energy utilization (Fig. 10).

\section{$\mathrm{PL} \rightarrow$ avBST pathway effects on passive coping behavior}

Our results endorse the $\mathrm{PL} \rightarrow$ avBST pathway in restraining passive, rather than driving active behavioral responses during ines- capable challenges. Whereas $\mathrm{PL} \rightarrow$ avBST pathway inactivation with two different opsins produced shifts from active (burying)to-passive (immobility) coping during the shock probe defensive burying test, pathway photostimulation decreased only passive, but not active, coping behavior. Thus, the decrease in burying observed during $\mathrm{PL} \rightarrow$ avBST pathway inhibition was likely due to the increased duration of immobility produced by this manipulation, whereas decreased immobility during pathway activation was not accompanied by an increase in burying. Moreover, the greater range of individual variability in burying behavior that remained in rats that received PL avBST activation (Fig. $7 d, e$ ) further supports a dissociation between the modulation of passive over active coping responses.

The ventrolateral PAG has been widely implicated in mediating passive coping behaviors in response to a variety of aversive stimuli in laboratory rodents (LeDoux et al., 1988; Bandler et al., 2000; Keay and Bandler, 2001; Tovote et al., 2016), and has recently been implicated in analogous responses in humans (Satpute et al., 2013). We recently uncovered a novel pathway involving avBST input to the ventrolateral PAG that modulates immobility behavior in response to inescapable challenges (Johnson et al., 2016). Our observation that inhibition of this pathway also increases passive coping behavior endorses a novel disynaptic $\mathrm{PL} \rightarrow$ avBST $\rightarrow$ ventrolateral PAG circuit capable of restraining passive coping responses during inescapable challenges. At first glance, the GABAergic phenotype of descending avBST projections (Fig. $5 i, j$ ) would be expected to gate passive coping behavior through the inhibition of output neurons in the ventrolateral PAG. However, the ventrolateral PAG contains an appreciable subpopulation of interneurons that may inhibit output neurons (Tovote et al., 2016). For instance, the central nucleus of the amygdala also issues GABAergic input to ventrolateral PAG and drives freezing behavior through a disinhibitory mechanism involving connections with local interneurons. Future studies will provide a clearer understanding of the circuit and synaptic mechanisms within the ventrolateral PAG that account for the gating influences of avBST over passive coping.

\section{$\mathrm{PL} \rightarrow$ avBST pathway modulation of HPA activation}

A wealth of evidence suggests that the $\mathrm{MPFC}$ may inhibit stressinduced HPA activation (Diorio et al., 1993; Akana et al., 2001; Figueiredo et al., 2003; Weinberg et al., 2010), and our past work implicates a $\mathrm{PL} \rightarrow$ avBST(GABA) $\rightarrow$ PVH pathway as a candidate in this regard (Radley et al., 2009). Our use of optogenetic approaches provides at least partial validation of this idea; that photoinhibition of the PL $\rightarrow$ avBST pathway enhanced stressinduced HPA activation. Yet, pathway photostimulation failed to attenuate HPA output. The current data may instead suggest a more permissive role for PL in restraining HPA activation in response to inescapable challenges, however, there are several alternatives explanations to consider. First, as mPFC does not provide any substantial innervation of the PVH, its HPAinhibitory influences of mPFC could be imparted via GABAergic relays in addition to avBST (Cullinan et al., 1993; Roland and Sawchenko, 1993). As such, each pathway could impart situationspecific influences over HPA activity that may be distinct from the PL input to avBST. Another possibility may involve the specific photostimulation parameters used. Our tract tracing data suggest that distinct subpopulations of avBST neurons issue projections to PVH and ventrolateral PAG (Fig. 4c). These subpopulations 
may have different response capacities for imparting downstream influences on their respective targets, such that $20-\mathrm{Hz}$ frequency during activational experiments may have engaged the avBST $\rightarrow$ ventrolateral PAG but not avBST $\rightarrow$ PVH. A final consideration is that, whereas the vast majority $(>90 \%)$ of avBST neurons are GABAergic (Cullinan et al., 1993; Poulin et al., 2009; Kudo et al., 2012), there is also evidence for a small subpopulation of glutamatergic neurons (Hur and Zaborsky, 2005; Poulin et al., 2009; Kudo et al., 2012), some of which may be PVH-projecting (Csáki et al., 2000). Thus, it is possible that $\mathrm{PL} \rightarrow$ avBST pathway activation could recruit GABAergic and non-GABAergic cell populations that may have countervailing effects on the HPA axis.

\section{Role of PL in adaptation to novel versus recurring challenges} From a purely circuit perspective, the ability of the PL to modulate behavioral output has commonly been assumed to occur through amygdaloid or midbrain structures. In PAG, PL may differentially modulate active and passive defensive behaviors through parallel axonal input to dorsal/ lateral and ventrolateral divisions, respectively, and also modulate other stress-adaptive behaviors via direct input the dorsal raphe nucleus (Floyd et al., 2000; Amat et al., 2005; Maier and Watkins, 2010; Warden et al., 2012; Challis et al., 2014; Franklin et al., 2017). Thus, our identification of a novel PL $\rightarrow$ avBST pathway in regulating passive coping during inescapable challenges adds to the diversity of circuit mechanisms by which PL influences behavior. Specifically, our data support this pathway as providing a higher point of integration for modulating behavioral coping and in coordinating this information across additional domains (endocrine, present study; autonomic, Crestani et al., 2013).

Our finding that activation of PL avBST decreases passive coping behavior, appears to be at odds with evidence that PL activation increases the expression of freezing behavior following fear conditioning (Vidal-Gonzalez et al., 2006; Corcoran and Quirk, 2007). However, theories of PL functioning encompass its modulation of behavior to optimize responses as commensurate with current task demands (Sharpe et al., 2018). Specific behavioral circumstances (e.g., acute challenges) may alter PL functioning and differentially engage specific output pathways, such as PL $\rightarrow$ avBST, whereas other contexts may engage different PL outputs, providing a mechanism by which the PL functions under a wide range of novel and recurring contexts. Thus, the PL $\rightarrow$ avBST pathway may be more engaged during exposure to novel, rather than recurring, challenges, whereas other PL circuits may be involved in the expression of fear conditioning and active avoidance learning (Corcoran and Quirk, 2007; Diehl et al., 2018).

\section{Relevance to coping strategies}

Different coping strategies involve distinct patterns of behavioral, physiological, and endocrine adjustments (Henry and Stephens, 1977; Korte et al., 2005), such that the coordination of these functions confers an adaptive advantage across a wide range of environmental conditions. Animals that tend toward aggression and/or proactive coping have been shown to mount a smaller HPA response, whereas those with low aggression and/or reactive coping display higher corticosterone levels (Henry and Stephens, 1977; Bohus et al., 1987; Sluyter et al., 1996; Koolhaas et al., 1999; Veenema et al., 2003, 2004; Walker et al., 2009). Our current study sheds light on the central organization of a passive response set that may meet the demands of adverse experiences in the short run. However, a single neural substrate capable of coordinating multiple features would appear to reduce response flexibility, and this arrangement may have detrimental consequences following situations of prolonged inescapable stress. Thus, it is perhaps not surprising that anxiety disorders and major depression commonly associated with chronic stress exposure, are also linked to passive coping strategies. Further, these disorders are more common in women than in men, and this disparity is associated with greater passive coping responses in women (Mueller and Bale, 2008; Goel and Bale, 2009; Goel et al., 2014; Shansky and Woolley, 2016). Although not part of the circuits considered in the present report, the posterior BST(especially the interfascicular and principal subdivisions of Dong and Swanson, 2004) is sexually dimorphic, at least anatomically (Hines et al., 1992), and has similar connections with upstream limbic and downstream hypothalamic and midbrain regions as avBST. Thus, future work should consider the extent to which sex and chronic stress may come to interact on $\mathrm{PL} \rightarrow \mathrm{avBST}$ and related pathways of interest.

\section{References}

Akana SF, Chu A, Soriano L, Dallman MF (2001) Corticosterone exerts sitespecific and state-dependent effects in prefrontal cortex and amygdala on regulation of adrenocorticotropic hormone, insulin and fat depots. J Neuroendocrinol 13:625-637. CrossRef Medline

Amat J, Baratta MV, Paul E, Bland ST, Watkins LR, Maier SF (2005) Medial prefrontal cortex determines how stressor controllability affects behavior and dorsal raphe nucleus. Nat Neurosci 8:365-371. CrossRef Medline

Assareh N, Sarrami M, Carrive P, McNally GP (2016) The organization of defensive behavior elicited by optogenetic excitation of rat lateral or ventrolateral periaqueductal gray. Behav Neurosci 130:406-414. CrossRef Medline

Bandler R, Keay KA, Floyd N, Price J (2000) Central circuits mediating patterned autonomic activity during active vs passive emotional coping. Brain Res Bull 53:95-104. CrossRef Medline

Bohus B, Benus RF, Fokkema DS, Koolhaas JM, Nyakas C, van Oortmerssen GA, Prins AJ, de Ruiter AJ, Scheurink AJ, Steffens AB (1987) Neuroendocrine states and behavioral and physiological stress responses. Prog Brain Res 72:57-70. CrossRef Medline

Boyden ES, Zhang F, Bamberg E, Nagel G, Deisseroth K (2005) Millisecondtimescale, genetically targeted optical control of neural activity. Nat Neurosci 8:1263-1268. CrossRef Medline

Celada P, Puig MV, Casanovas JM, Guillazo G, Artigas F (2001) Control of dorsal raphe serotonergic neurons by the medial prefrontal cortex: involvement of serotonin-1A, $\mathrm{GABA}_{\mathrm{A}}$, and glutamate receptors. J Neurosci 21:9917-9929. CrossRef Medline

Challis C, Beck SG, Berton O (2014) Optogenetic modulation of descending prefrontocortical inputs to the dorsal raphe bidirectionally bias socioaffective choices after social defeat. Front Behav Neurosci 8:43. CrossRef Medline

Chang YC, Gottlieb DI (1988) Characterization of the proteins purified with monoclonal antibodies to glutamic acid decarboxylase. J Neurosci 8:2123-2130. CrossRef Medline

Chermat R, Thierry B, Mico JA, Steru L, Simon P (1986) Adaptation of the tail suspension test to the rat. J Pharmacol 17:348-350. Medline

Chiba T, Kayahara T, Nakano K (2001) Efferent projections of infralimbic and prelimbic areas of the medial prefrontal cortex in the Japanese monkey, Macaca fuscata. Brain Res 888:83-101. CrossRef Medline

Choi DC, Evanson NK, Furay AR, Ulrich-Lai YM, Ostrander MM, Herman JP (2008) The anteroventral bed nucleus of the stria terminalis differentially regulates hypothalamic-pituitary-adrenocortical axis responses to acute and chronic stress. Endocrinology 149:818-826. CrossRef Medline

Chow BY, Han X, Dobry AS, Qian X, Chuong AS, Li M, Henninger MA, Belfort GM, Lin Y, Monahan PE, Boyden ES (2010) High-performance 
genetically targetable optical neural silencing by light-driven proton pumps. Nature 463:98-102. CrossRef Medline

Corcoran KA, Quirk GJ (2007) Activity in prelimbic cortex is necessary for the expression of learned, but not innate, fears. J Neurosci 27:840-844. CrossRef Medline

Crestani CC, Alves FH, Gomes FV, Resstel LB, Correa FM, Herman JP (2013) Mechanisms in the bed nucleus of the stria terminalis involved in control of autonomic and neuroendocrine functions: a review. Curr Neuropharmacol 11:141-159. CrossRef Medline

Csáki A, Kocsis K, Halasz B, Kiss J (2000) Localization of glutamatergic/ aspartatergic neurons projecting to the hypothalamic paraventricular nucleus studied by retrograde transport of [3H]D-aspartate autoradiography. Neuroscience 101:637-655. CrossRef Medline

Cullinan WE, Herman JP, Watson SJ (1993) Ventral subicular interaction with the hypothalamic paraventricular nucleus: evidence for a relay in the bed nucleus of the stria terminalis. J Comp Neurol 332:1-20. CrossRef Medline

Daniel SE, Rainnie DG (2016) Stress modulation of opposing circuits in the bed nucleus of the stria terminalis. Neuropsychopharmacology 41:103125. CrossRef Medline

Davis M, Walker DL, Miles L, Grillon C (2010) Phasic vs sustained fear in rats and humans: role of the extended amygdala in fear vs anxiety. Neuropsychopharmacology 35:105-135. CrossRef Medline

Day TA (2005) Defining stress as a prelude to mapping its neurocircuitry: no help from allostasis. Prog Neuropsychopharmacol Biol Psychiatry 29: 1195-1200. CrossRef Medline

De Boer SF, Koolhaas JM (2003) Defensive burying in rodents: ethology, neurobiology and psychopharmacology. Eur J Pharmacol 463:145-161. CrossRef Medline

Diehl MM, Bravo-Rivera C, Rodriguez-Romaguera J, Pagan-Rivera PA, Burgos-Robles A, Roman-Ortiz C, Quirk GJ (2018) Active avoidance requires inhibitory signaling in the rodent prelimbic prefrontal cortex. eLife 7:e34657. CrossRef Medline

Diorio D, Viau V, Meaney MJ (1993) The role of the medial prefrontal cortex (cingulate gyrus) in the regulation of hypothalamic-pituitaryadrenal responses to stress. J Neurosci 13:3839-3847. CrossRef Medline

Dong HW, Swanson LW (2004) Projections from bed nuclei of the stria terminalis, posterior division: implications for cerebral hemisphere regulation of defensive and reproductive behaviors. J Comp Neurol 471:396433. CrossRef Medline

Dong HW, Swanson LW (2006) Projections from bed nuclei of the stria terminalis, dorsomedial nucleus: implications for cerebral hemisphere integration of neuroendocrine, autonomic, and drinking responses. J Comp Neurol 494:75-107. CrossRef Medline

Dong HW, Petrovich GD, Watts AG, Swanson LW (2001) Basic organization of projections from the oval and fusiform nuclei of the bed nuclei of the stria terminalis in adult rat brain. J Comp Neurol 436:430-455. CrossRef Medline

Ericsson A, Kovács KJ, Sawchenko PE (1994) A functional anatomical analysis of central pathways subserving the effects of interleukin-1 on stressrelated neuroendocrine neurons. J Neurosci 14:897-913. CrossRef Medline

Esclapez M, Tillakaratne NJ, Tobin AJ, Houser CR (1993) Comparative localization of mRNAs encoding two forms of glutamic acid decarboxylase with nonradioactive in situ hybridization methods. J Comp Neurol 331: 339-362. CrossRef Medline

Figueiredo HF, Bruestle A, Bodie B, Dolgas CM, Herman JP (2003) The medial prefrontal cortex differentially regulates stress-induced c-fos expression in the forebrain depending on type of stressor. Eur J Neurosci 18:2357-2364. CrossRef Medline

Fisk GD, Wyss JM (1997) Pressor and depressor sites are intermingled in the cingulate cortex of the rat. Brain Res 754:204-212. CrossRef Medline

Floyd NS, Price JL, Ferry AT, Keay KA, Bandler R (2000) Orbitomedial prefrontal cortical projections to distinct longitudinal columns of the periaqueductal gray in the rat. J Comp Neurol 422:556-578. CrossRef Medline

Fox AS, Oler JA, Tromp do PM, Fudge JL, Kalin NH (2015) Extending the amygdala in theories of threat processing. Trends Neurosci 38:319-329. CrossRef Medline

Franklin TB, Silva BA, Perova Z, Marrone L, Masferrer ME, Zhan Y, Kaplan A, Greetham L, Verrechia V, Halman A, Pagella S, Vyssotski AL, Illarionova A, Grinevich V, Branco T, Gross CT (2017) Prefrontal cortical control of a brainstem social behavior circuit. Nat Neurosci 20:260-270. CrossRef Medline

Gilmartin MR, Balderston NL, Helmstetter FJ (2014) Prefrontal cortical regulation of fear learning. Trends Neurosci 37:455-464. CrossRef Medline

Glangetas C, Massi L, Fois GR, Jalabert M, Girard D, Diana M, Yonehara K, Roska B, Xu C, Luthi A, Caille S, Georges F (2017) NMDA-receptordependent plasticity in the bed nucleus of the stria terminalis triggers long-term anxiolysis. Nat Commun 8:14456. CrossRef Medline

Goel N, Bale TL (2009) Examining the intersection of sex and stress in modelling neuropsychiatric disorders. J Neuroendocrinol 21:415-420. CrossRef Medline

Goel N, Workman JL, Lee TT, Innala L, Viau V (2014) Sex differences in the HPA axis. Compr Physiol 4:1121-1155. CrossRef Medline

Gourley SL, Kedves AT, Olausson P, Taylor JR (2009) A history of corticosterone exposure regulates fear extinction and cortical NR2B, GluR2/3, and BDNF. Neuropsychopharmacology 34:707-716. CrossRef Medline

Han X, Boyden ES (2007) Multiple-color optical activation, silencing, and desynchronization of neural activity, with single-spike temporal resolution. PloS One 2:e299. CrossRef Medline

Heesch CM, Negus BH, Keffer JH, Snyder RW 2nd, Risser RC, Eichhorn EJ (1995) Effects of cocaine on cortisol secretion in humans. Am J Med Sci 310:61-64. CrossRef Medline

Henry JP (1992) Biological basis of the stress response. Integr Physiol Behav Sci 27:66-83. CrossRef Medline

Henry JP, Stephens PM (1977) Stress, health and the social environment: a sociaobiological approach to medicine. Berlin: Springer.

Herman JP, Cullinan WE, Watson SJ (1994) Involvement of the bed nucleus of the stria terminalis in tonic regulation of paraventricular hypothalamic CRH and AVP mRNA expression. J Neuroendocrinol 6:433-442. CrossRef Medline

Hines M, Allen LS, Gorski RA (1992) Sex differences in subregions of the medial nucleus of the amygdala and the bed nucleus of the stria terminalis of the rat. Brain Res 579:321-326. CrossRef Medline

Huff ML, Miller RL, Deisseroth K, Moorman DE, LaLumiere RT (2013) Posttraining optogenetic manipulations of basolateral amygdala activity modulate consolidation of inhibitory avoidance memory in rats. Proc Natl Acad Sci U S A 110:3597-3602. CrossRef Medline

Hur EE, Zaborszky L (2005) Vglut2 afferents to the medial prefrontal and primary somatosensory cortices: a combined retrograde tracing in situ hybridization study [corrected]. J Comp Neurol 483:351-373. CrossRef Medline

Hurley KM, Herbert H, Moga MM, Saper CB (1991) Efferent projections of the infralimbic cortex of the rat. J Comp Neurol 308:249-276. CrossRef Medline

Izumi J, Washizuka M, Hayashi Kuwabara Y, Yoshinaga K, Tanaka Y, Ikeda Y, Kiuchi Y, Oguchi K (1997) Evidence for a depressive-like state induced by repeated saline injections in fischer 344 rats. Pharmacol Biochem Behav 57:883-888. CrossRef Medline

Johnson SB, Emmons EB, Anderson RM, Glanz RM, Romig-Martin SA, Narayanan NS, LaLumiere RT, Radley JJ (2016) A basal forebrain site coordinates the modulation of endocrine and behavioral stress responses via divergent neural pathways. J Neurosci 36:8687-8699. CrossRef Medline

Keay KA, Bandler R (2001) Parallel circuits mediating distinct emotional coping reactions to different types of stress. Neurosci Biobehav Rev 25: 669-678. CrossRef Medline

Koolhaas JM (2008) Coping style and immunity in animals: making sense of individual variation. Brain Behav Immun 22:662-667. CrossRef Medline

Koolhaas JM, Korte SM, De Boer SF, Van Der Vegt BJ, Van Reenen CG, Hopster H, De Jong IC, Ruis MA, Blokhuis HJ (1999) Coping styles in animals: current status in behavior and stress-physiology. Neurosci Biobehav Rev 23:925-935. CrossRef Medline

Korte SM, Koolhaas JM, Wingfield JC, McEwen BS (2005) The darwinian concept of stress: benefits of allostasis and costs of allostatic load and the trade-offs in health and disease. Neurosci Biobehav Rev 29:3-38. CrossRef Medline

Krause EG, de Kloet AD, Flak JN, Smeltzer MD, Solomon MB, Evanson NK, Woods SC, Sakai RR, Herman JP (2011) Hydration state controls stress responsiveness and social behavior. J Neurosci 31:5470-5476. CrossRef Medline

Krettek JE, Price JL (1977) The cortical projections of the mediodorsal 
nucleus and adjacent thalamic nuclei in the rat. J Comp Neurol 171:157191. CrossRef Medline

Kudo T, Uchigashima M, Miyazaki T, Konno K, Yamasaki M, Yanagawa Y, Minami M, Watanabe M (2012) Three types of neurochemical projection from the bed nucleus of the stria terminalis to the ventral tegmental area in adult mice. J Neurosci 32:18035-18046. CrossRef Medline

Lebow MA, Chen A (2016) Overshadowed by the amygdala: the bed nucleus of the stria terminalis emerges as key to psychiatric disorders. Mol Psychiatry 21:450-463. CrossRef Medline

LeDoux JE, Iwata J, Cicchetti P, Reis DJ (1988) Different projections of the central amygdaloid nucleus mediate autonomic and behavioralcorrelates of conditioned fear. J Neurosci 8:2517-2529. CrossRef Medline

Loewy AD, McKellar S (1980) The neuroanatomical basis of central cardiovascular control. Fed Proc 39:2495-2503.

Maier SF, Watkins LR (2010) Role of the medial prefrontal cortex in coping and resilience. Brain Res 1355:52-60. CrossRef Medline

Mason JW (1975) A historical view of the stress field. J Human Stress 1:2236. CrossRef Medline

Mason JW, Maher JT, Hartley LH, Mougey EH, Perlow MJ, Jones LG (1976) Selectivity of corticosteroid and catecholamine responses to various natural stimuli. New York: Springer.

Moga MM, Saper CB (1994) Neuropeptide-immunoreactive neurons projecting to the paraventricular hypothalamic nucleus in the rat. J Comp Neurol 346:137-150. CrossRef Medline

Morgan MA, LeDoux JE (1995) Differential contribution of dorsal and ventral medial prefrontal cortex to the acquisition and extinction of conditioned fear in rats. Behav Neurosci 109:681-688. CrossRef Medline

Mueller BR, Bale TL (2008) Sex-specific programming of offspring emotionality after stress early in pregnancy. J Neurosci 28:9055-9065. CrossRef Medline

Myers B, McKlveen JM, Herman JP (2014) Glucocorticoid actions on synapses, circuits, and behavior: implications for the energetics of stress. Front Neuroendocrinol 35:180-196. CrossRef Medline

Neafsey EJ (1990) Prefrontal cortical control of the autonomic nervous system: anatomical and physiological observations. Prog Brain Res 85:147166. CrossRef Medline

Paumier KL, Sortwell CE, Madhavan L, Terpstra B, Celano SL, Green JJ, Imus NM, Marckini N, Daley B, Steece-Collier K, Collier TJ (2015) Chronic amitriptyline treatment attenuates nigrostriatal degeneration and significantly alters trophic support in a rat model of parkinsonism. Neuropsychopharmacology 40:874-883. CrossRef Medline

Poulin JF, Arbour D, Laforest S, Drolet G (2009) Neuroanatomical characterization of endogenous opioids in the bed nucleus of the stria terminalis. Prog Neuropsychopharmacol Biol Psychiatry 33:1356-1365. CrossRef Medline

Radley JJ, Sawchenko PE (2011) A common substrate for prefrontal and hippocampal inhibition of the neuroendocrine stress response. J Neurosci 31:9683-9695. CrossRef Medline

Radley JJ, Sawchenko PE (2015) Evidence for involvement of a limbic paraventricular hypothalamic inhibitory network in hypothalamic-pituitaryadrenal axis adaptations to repeated stress. J Comp Neurol 523: 2769-2787. CrossRef Medline

Radley JJ, Arias CM, Sawchenko PE (2006) Regional differentiation of the medial prefrontal cortex in regulating adaptive responses to acute emotional stress. J Neurosci 26:12967-12976. CrossRef Medline

Radley JJ, Gosselink KL, Sawchenko PE (2009) A discrete GABAergic relay mediates medial prefrontal cortical inhibition of the neuroendocrine stress response. J Neurosci 29:7330-7340. CrossRef Medline

Radley JJ, Anderson RM, Hamilton BA, Alcock JA, Romig-Martin SA (2013) Chronic stress-induced alterations of dendritic spine subtypes predict functional decrements in an hypothalamo-pituitary-adrenal-inhibitory prefrontal circuit. J Neurosci 33:14379-14391. CrossRef Medline

Ramirez S, Liu X, MacDonald CJ, Moffa A, Zhou J, Redondo RL, Tonegawa S (2015) Activating positive memory engrams suppresses depression-like behaviour. Nature 522:335-339. CrossRef Medline

Roland BL, Sawchenko PE (1993) Local origins of some GABAergic projections to the paraventricular and supraoptic nuclei of the hypothalamus in the rat. J Comp Neurol 332:123-143. CrossRef Medline

Satpute AB, Wager TD, Cohen-Adad J, Bianciardi M, Choi JK, Buhle JT, Wald LL, Barrett LF (2013) Identification of discrete functional subregions of the human periaqueductal gray. Proc Natl Acad Sci U S A 110:1710117106. CrossRef Medline
Selye H (1980) Stress in health and disease. Boston: Butterworths.

Sesack SR, Deutch AY, Roth RH, Bunney BS (1989) Topographical organization of the efferent projections of the medial prefrontal cortex in the rat: an anterograde tract-tracing study with phaseolus vulgaris leucoagglutinin. J Comp Neurol 290:213-242. CrossRef Medline

Shansky RM, Woolley CS (2016) Considering sex as a biological variable will be valuable for neuroscience research. J Neurosci 36:11817-11822. CrossRef Medline

Sharpe MJ, Stalnaker T, Schuck NW, Killcross S, Schoenbaum G, Niv Y (2018) An integrated model of action selection: distinct modes of cortical control of striatal decision making. Annu Rev Psychol. Advance online publication. Retrieved September 27, 2018. doi:10.1146/annurev-psych010418-102824.

Sluyter F, Korte SM, Bohus B, Van Oortmerssen GA (1996) Behavioral stress response of genetically selected aggressive and nonaggressive wild house mice in the shock-probe/defensive burying test. Pharmacol Biochem Behav 54:113-116. CrossRef Medline

Sotres-Bayon F, Quirk GJ (2010) Prefrontal control of fear: more than just extinction. Curr Opin Neurobiol 20:231-235. CrossRef Medline

Spencer SJ, Buller KM, Day TA (2005) Medial prefrontal cortex control of the paraventricular hypothalamic nucleus response to psychological stress: possible role of the bed nucleus of the stria terminalis. J Comp Neurol 481:363-376. CrossRef Medline

Steru L, Chermat R, Thierry B, Simon P (1985) The tail suspension test: a new method for screening antidepressants in mice. Psychopharmacology 85:367-370. CrossRef Medline

Stone EA, Lin Y (2008) An anti-immobility effect of exogenous corticosterone in mice. Eur J Pharmacol 580:135-142. CrossRef Medline

Strekalova T, Spanagel R, Bartsch D, Henn FA, Gass P (2004) Stressinduced anhedonia in mice is associated with deficits in forced swimming and exploration. Neuropsychopharmacology 29:2007-2017. CrossRef Medline

Swanson LW (2004) Brain maps: structure of the rat brain. Amsterdam: Elsevier.

Swanson LW, Sawchenko PE (1983) Hypothalamic integration: organization of the paraventricular and supraoptic nuclei. Annu Rev Neurosci 6:269_ 324. CrossRef Medline

Tavares RF, Corrêa FM, Resstel LB (2009) Opposite role of infralimbic and prelimbic cortex in the tachycardiac response evoked by acute restraint stress in rats. J Neurosci Res 87:2601-2607. CrossRef Medline

Tovote P, Esposito MS, Botta P, Chaudun F, Fadok JP, Markovic M, Wolff SB, Ramakrishnan C, Fenno L, Deisseroth K, Herry C, Arber S, Lüthi A (2016) Midbrain circuits for defensive behaviour. Nature 534:206-212. CrossRef Medline

Treit D, Pinel JP, Fibiger HC (1981) Conditioned defensive burying: a new paradigm for the study of anxiolytic agents. Pharmacol Biochem Behav 15:619-626. CrossRef Medline

Van De Werd HJ, Uylings HB (2008) The rat orbital and agranular insular prefrontal cortical areas: a cytoarchitectonic and chemoarchitectonic study. Brain Struct Funct 212:387-401. CrossRef Medline

Veenema AH, Meijer OC, de Kloet ER, Koolhaas JM, Bohus BG (2003) Differences in basal and stress-induced HPA regulation of wild house mice selected for high and low aggression. Horm Behav 43:197-204. CrossRef Medline

Veenema AH, Koolhaas JM, de Kloet ER (2004) Basal and stress-induced differences in HPA axis, 5-HT responsiveness, and hippocampal cell proliferation in two mouse lines. Ann N Y Acad Sci 1018:255-265. CrossRef Medline

Vertes RP (2004) Differential projections of the infralimbic and prelimbic cortex in the rat. Synapse 51:32-58. CrossRef Medline

Vidal-Gonzalez I, Vidal-Gonzalez B, Rauch SL, Quirk GJ (2006) Microstimulation reveals opposing influences of prelimbic and infralimbic cortex on the expression of conditioned fear. Learn Mem 13:728-733. CrossRef Medline

Vogt BA, Peters A (1981) Form and distribution of neurons in rat cingulate cortex: areas 32, 24, and 29. J Comp Neurol 195:603-625. CrossRef Medline

Walker DL, Toufexis DJ, Davis M (2003) Role of the bed nucleus of the stria terminalis versus the amygdala in fear, stress, and anxiety. Eur J Pharmacol 463:199-216. CrossRef Medline 
Walker FR, Masters LM, Dielenberg RA, Day TA (2009) Coping with defeat: acute glucocorticoid and forebrain responses to social defeat vary with defeat episode behaviour. Neuroscience 162:244-253. CrossRef Medline

Warden MR, Selimbeyoglu A, Mirzabekov JJ, Lo M, Thompson KR, Kim SY, Adhikari A, Tye KM, Frank LM, Deisseroth K (2012) A prefrontal cortex-brainstem neuronal projection that controls response to behavioural challenge. Nature 492:428-432. CrossRef Medline

Weinberg MS, Johnson DC, Bhatt AP, Spencer RL (2010) Medial prefrontal cortex activity can disrupt the expression of stress response habituation. Neuroscience 168:744-756. CrossRef Medline

Yang SJ, Yu HY, Kang DY, Ma ZQ, Qu R, Fu Q, Ma SP (2014) Antidepressant-like effects of salidroside on olfactory bulbectomy- induced pro-inflammatory cytokine production and hyperactivity of HPA axis in rats. Pharmacol Biochem Behav 124:451-457. CrossRef Medline

Yizhar O, Fenno LE, Davidson TJ, Mogri M, Deisseroth K (2011) Optogenetics in neural systems. Neuron 71:9-34. CrossRef Medline

Yu G, Sharp BM (2012) Nicotine modulates multiple regions in the limbic stress network regulating activation of hypophysiotrophic neurons in hypothalamic paraventricular nucleus. J Neurochem 122:628-640. CrossRef Medline

Zhang L, Hernández VS, Medina-Pizarro M, Valle-Leija P, Vega-González A, Morales T (2008) Maternal hyperthyroidism in rats impairs stress coping of adult offspring. J Neurosci Res 86:1306-1315. CrossRef Medline 